\title{
Recent scenario of airborne pollens of Lucknow, India with special reference to intra- and interannual, diurnal, and vertical variation
}

This article was published in the following Dove Press journal:

Research and Reports in Biodiversity Studies

10 October 2012

Number of times this article has been viewed

\section{Kalyani Datta \\ Avijeet Chatterjee \\ Deepti Nigam \\ Sudhir P Singh \\ Praveen C Verma}

National Botanical Research Institute (CSIR), Rana Pratap Marg, Lucknow, Uttar Pradesh, India
Correspondence: Praveen C Verma CPMB, National Botanical Research Institute, (CSIR), Rana Pratap Marg, Lucknow - 22600 I (UP), India Tel +9l 5222297922 ext 944 Fax +9I 5222205836

Email praveencverma@yahoo.com
Abstract: Biomonitoring of airborne pollen in Lucknow, India was conducted for 2 consecutive years (August 2005-July 2007) with the objective of assessing the recent status of airborne pollen of the city and analyzing the intra- and interannual variations. Determination of total incidence of airborne pollen with subsequent contributions of individual components was carried out by measuring diurnal and vertical gradients. The Pearson correlation test was conducted to analyze pollen counts for 2 successive years. Principal component analysis was also carried out to examine the relative distribution of major pollen samples according to their dominance in the particular environment for 2 consecutive years. A total of 6089 pollen grains were caught in 2005-2006, which included 77 types against 4335 pollen grains comprising 61 types registered in 2006-2007. Two major pollen seasons, ie, spring and autumn, were confirmed. During 2005-2006, the highest airborne pollen concentration was found in February $\left(154.67 / \mathrm{m}^{3}\right)$, while the spring pollen peak was shifted to March $\left(133.7 / \mathrm{m}^{3}\right)$ in the consecutive year. The second pollen peak in both years was in August, which included mostly grass pollen. The highest airborne pollen contributor of 2005-2006 was grass, accounting for $25 \%$ of total pollen, while in the subsequent year Holoptelea dominated with $47 \%$ of total pollen. The diurnal analysis showed that the highest pollen concentration in 2005-2006 was around $2 \mathrm{pm}$ due to abundant flowering of Morus, while in 2006-2007, the maximum concentration was reported at 10 am due to Holoptelea pollen. Inter-annual species variation in climate was also considered as an important factor involved in inter-annual variation in pollen incidence. In general, a positive correlation was observed with temperature, particularly average temperature. During each period, peak pollen counts occurred when the average temperature fell within the range of $22^{\circ} \mathrm{C}-23^{\circ} \mathrm{C}$.

Keywords: airborne pollen, diurnal fluctuation, inter-annual variation, pollen incidence

\section{Introduction}

Many different types of pollen are dispersed in the atmosphere. Pollen dispersal patterns in the atmosphere reflect the flowering phenology and pollen productivity of the regional flora. Their atmospheric presence and concentration were strongly influenced by meteorological, biological, and topographical factors. ${ }^{1,2}$ Because many airborne pollen are causative factors of several types of allergic disorders in the human population, aerobiological surveys have been carried out in most regions of the developed and developing world in the second half of the last century. ${ }^{3-9}$

A number of aerobiological surveys have already been conducted in many Indian cities, including Lucknow. ${ }^{10-14}$ As the composition of the ground vegetation is changing 
due to many anthropogenic causes such as urbanization as well as natural causes such as climate variations, aerospora is becoming altered. ${ }^{15,16}$ Hence, new surveys are mandatory to update the knowledge regarding prevailing atmospheric pollen grains. ${ }^{17}$ A survey of airborne pollen grains of Lucknow was conducted as early as $1954-1955^{18}$ and subsequent surveys were performed in 1969-1970 ${ }^{19}$ and 1980-1981.20 All of these surveys were based on gravitational methods of sampling and therefore presented qualitative data of pollen incidence. A rotorod sampler working on impaction device was used for a one-year survey of aerospora in Lucknow in $1997 .^{21}$

The present survey was conducted to assess both the qualitative and quantitative status of airborne pollen grains in Lucknow using a volumetric sampler. Both diurnal and vertical gradients were used as the sampling was conducted three times daily at three different heights to analyze the periodical and vertical variation of airborne pollen for two consecutive years (August 2005-July 2007) to identify intra- and inter-annual variation of dominant aerial pollen in Lucknow.

\section{Materials and methods Study area}

Airborne pollen monitoring was conducted for two consecutive years (August 1, 2005-July 31, 2007) at the National
Botanical Research Institute, which is situated in the heart of Lucknow $\left(80^{\circ} 59^{\prime} \mathrm{E}, 26^{\circ} 55^{\prime} \mathrm{N}\right)$, in the capital city of Uttar Pradesh, India (Figure 1). Lucknow has a warm subtropical climate with cool, dry winters from December to February and dry, hot summers from April to June. The rainy season is from mid-June to mid-September. In winter, the maximum temperature is around $21^{\circ} \mathrm{C}$ and the minimum is $3^{\circ} \mathrm{C}$ to $4^{\circ} \mathrm{C}$. Fog is quite common from late December to late January. Summers can be quite hot with temperatures rising to the $40^{\circ} \mathrm{C}$ to $45^{\circ} \mathrm{C}$ range.

\section{Aerobiological survey: pollen collection, identification, and counting}

A daily pollen count was performed during two consecutive years (August 2005-July 2007) using a Burkard volumetric portable air sampler (Burkard Manufacturing, Rickmansworth, Hertfordshire, UK), which operates at a nominal air throughput of ten $1 / \mathrm{min}$. Glass slides were labeled and then prepared using a very thin film of a high-quality red-stained glycerin jelly to collect the pollen. The slide was then placed in the Burkard sampler and allowed to run for approximately 15 min each time daily at $10 \mathrm{am}, 2 \mathrm{pm}$, and $5 \mathrm{pm}$ at heights of $0.12 \mathrm{~m}, 3.048 \mathrm{~m}$, and $9.144 \mathrm{~m}$. The exposed area of the micro-slide was covered with $24 \times 24-\mathrm{mm}$ cover glass and analyzed under a light microscope (Olympus CM3 microscope; Olympus, Tokyo, Japan) with the reading method of

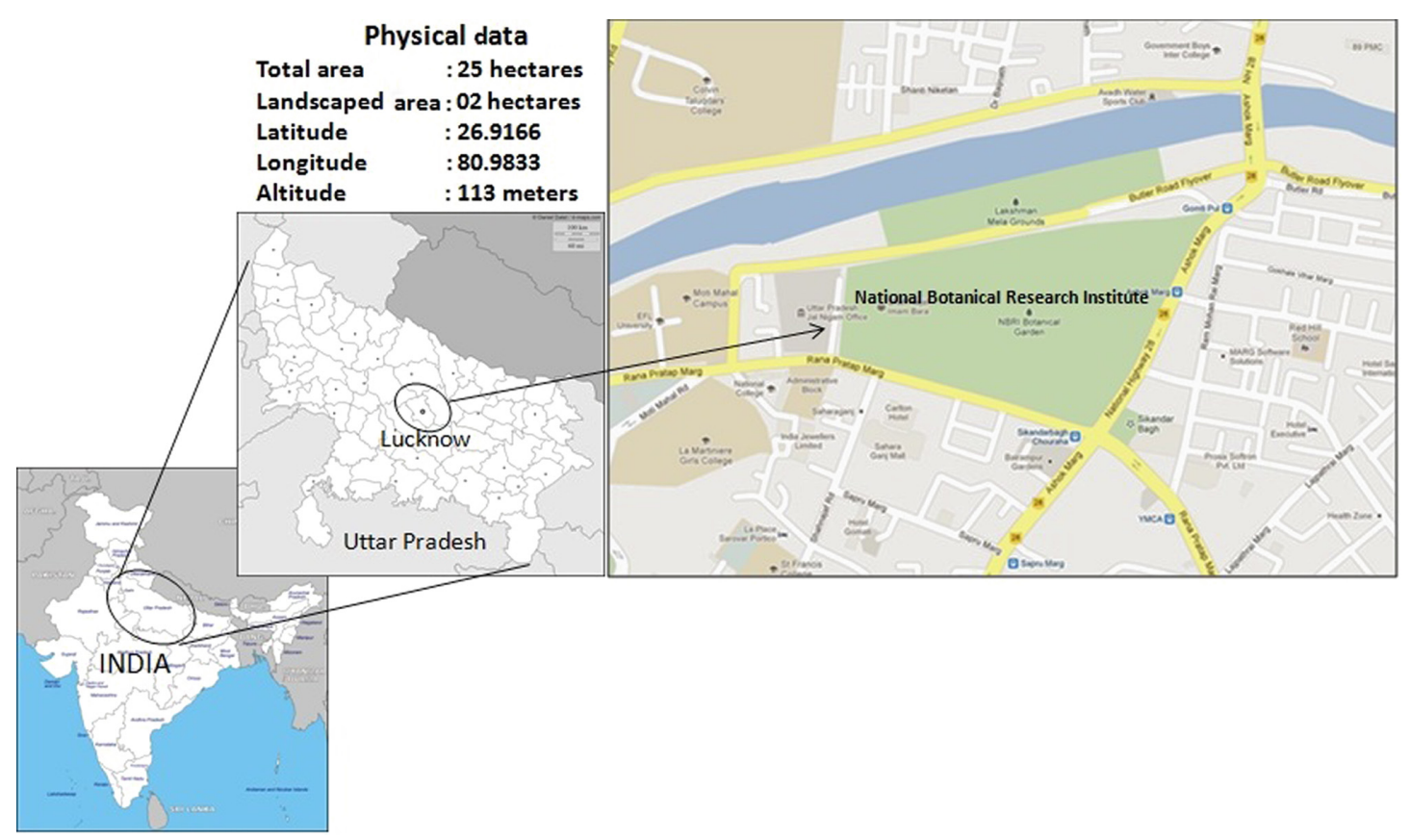

Figure I Site of the study (National Botanical Research Institute, Lucknow, India). 
parallel smear with tangential microscope fields. With this method, successive tangent fields positioned on four or five lines separated by a space of about $2 \mathrm{~mm}$ were examined at $400 \times$ magnification $(10 \times$ ocular lens and $40 \times$ objective lens).

After counting the pollen grains in one field, the slide was moved to the next tangential field. The pollen grains were then calculated for the entire exposed sample area, and this calculation was the final pollen count. Depending on the number of lines counted and the diameter of each field, pollen concentration per cubic meter was calculated. For reference purposes, acetolyzed pollen grains $^{22}$ of identified taxa were prepared. Pollen types were identified to species level (if possible) or at the genus level and grouped by family. Pollen types were identified by comparison with slides from the palynotheca and pollen kits of the Palynology Division, NBRI, Lucknow, India. Bibliographies ${ }^{22,23}$ were also consulted for material identification.

\section{Meteorological data}

Daily maximum and minimum temperature, rainfall, and relative humidity (RH, \%) from August 2005 to July 2007 were obtained from local weather information on the Website of the India Meteorological Department (http:// www.mausam.gov.in/WEBIMD/). Simultaneous computing of mean monthly temperature and $\mathrm{RH}$ was carried out to find the correlation matrix of the pollen count with the weather variables. For the correlation of pollen incidence with phenological corollary, a study of ground vegetation was conducted.

\section{Statistical analysis}

Statistical analysis was performed for the identification of year-wise or seasonal differences in pollen count based on different ground vegetation. Pearson correlation (r-squared value, ie, correlation coefficient) was also calculated using the linear equation $\mathrm{y}=\mathrm{mx}+\mathrm{b}$ in order to establish the correlation between yearly pollen counts. The analysis was performed for $\log _{2}$-transformed pollen counts data of all the species over two different years (between 12 months of 2 successive years, ie, 2005-2006 and 2006-2007). The unsupervised pattern recognition technique, or principal component analysis (PCA) was conducted using SAS software (v. 9.1.3; SAS Institute, Cary, NC). PCA was performed on the raw pollen count data after centering and auto-scaling of the variables. ${ }^{24}$ Through this approach, we were able to determine the variable discriminates between pollen grains for 14 and 11 major pollen types between 2005-2006 and 2006-2007, respectively.

PCA was also used to derive the first principal components from the data, and used in further analysis to examine the grouping of samples, ie, pollen count from different species, outliers, and to visualize the relative distribution of the major pollen samples according to their dominance in the particular environment. PCA was performed on the

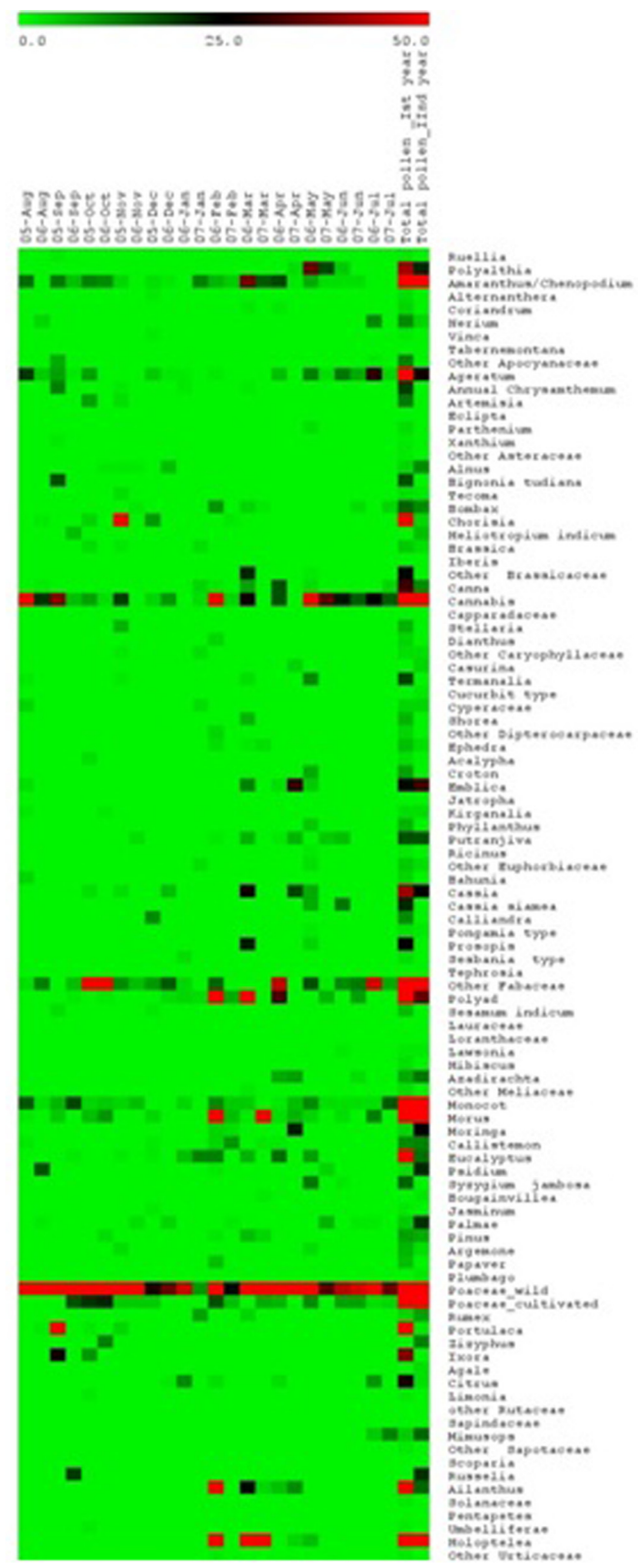

Figure 2 Pollen calendar for monthly incidence of individual airborne types (less, average, peak number) and their annual totals in Lucknow atmosphere for the years 2005-2007. 
matrix obtained from the standardized data for pollen counts during the major pollen peaks. The first principal component represented the largest portion of the variability of the original dataset, while the second principal component represents the second largest, and so on. ${ }^{25}$

\section{Results}

\section{Pollen sums}

Atmospheric pollen monitoring and subsequent microscopic analysis for 2 consecutive years confirmed two main pollen seasons in Lucknow, including spring and autumn; intra- and interannual variations of pollen incidence were also noted (Figure 2 and Supplementary file 1). A total of 6089 pollen grains consisting of 92 types were recorded during 2005-2006. Of 92 pollen types, the pollen of ten plant taxa contributed more than $1 \%$ of total airborne pollen, with the rest present at lower frequencies (Figure 3). Grass pollen grains were found to be major pollen contributors during 2005-2006, registering 25\% of the total catch followed by Holoptelea (20\%) and Morus (15\%). During 2005-2006, the highest airborne pollen contributor month was February, with a total of 2772 pollen grains and an airborne pollen concentration of 154.67 pollen grains $/ \mathrm{m}^{3}$, followed by August, with 30.16 pollen grains $/ \mathrm{m}^{3}$ (Figure $4 \mathrm{~A}$ and C). During 2006-2007, the total pollen catch was 4335 and included 61 pollen types, with the highest pollen peak observed in March (Figure 4B and D) with total of 2525 pollen grains. In contrast to the ten plants contributing more than $1 \%$ of total airborne pollen in 2005-2006, during 2006-2007, only seven plants registered more than $1 \%$ of total pollen (Figure 3 ).

\section{Statistical analysis}

\section{Pearson correlation test}

The correlation coefficient was measured for pollen count data for 12 months in 2 successive years, 2005-2006 and 2006-2007, using the linear equation $\mathrm{y}=\mathrm{mx}+\mathrm{b}$. We observed a nearly linear distribution for these two logarithmic transformed data (ie, $\log _{2}$ transformation) (Figure 5A and Supplementary file 2). The value was found to be 0.486 , which is close to the expected correlation value of approximately 0.5 and follows a nearly linear equation. Further, it could also be inferred that there was no significant correlation $(\geq 0.5)$ between the measured values of total

Year 2005-2006

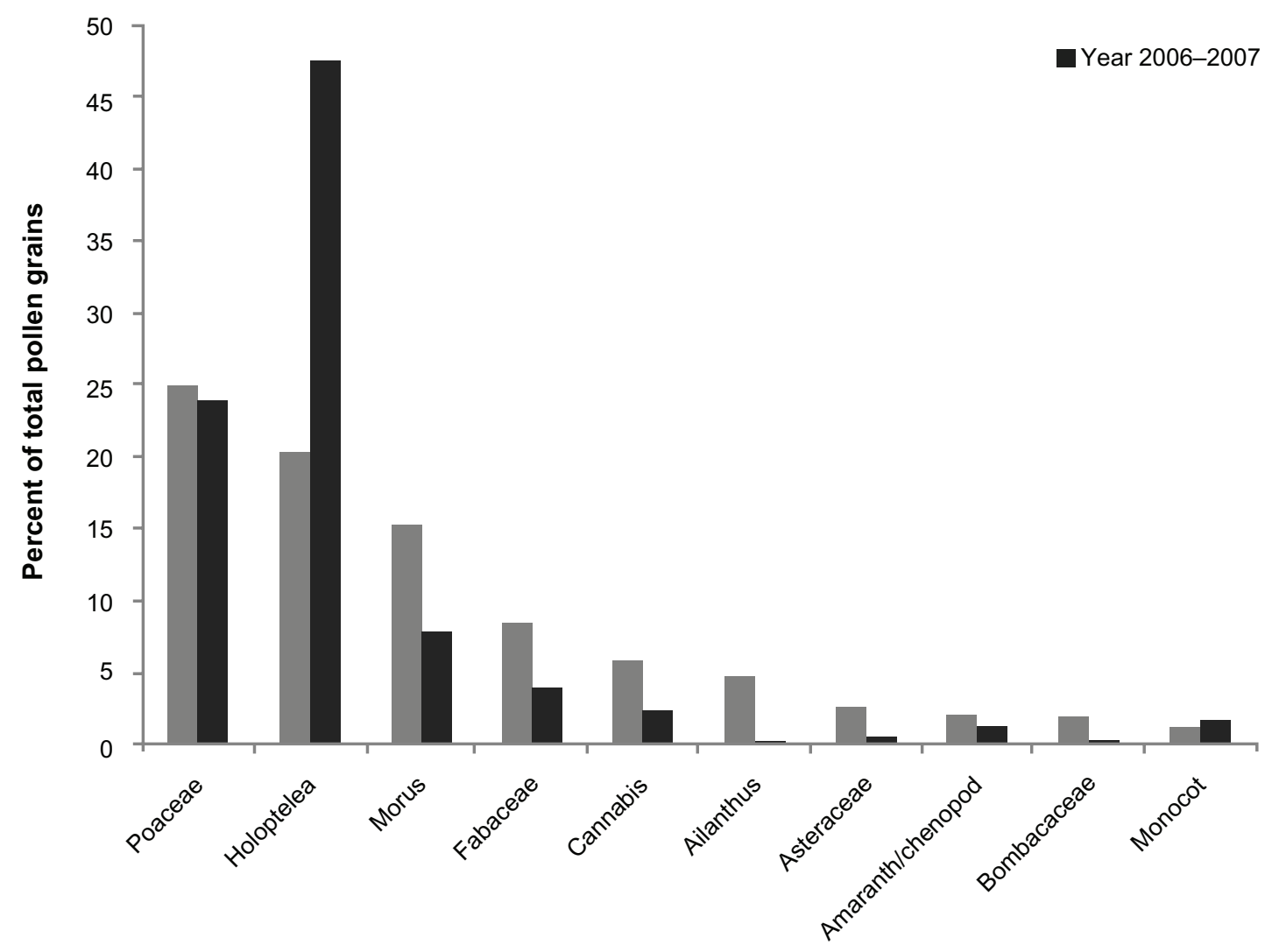

Figure 3 Percentage contribution of major pollen types in Lucknow atmosphere from August 2005-July 2006 and August $2006-J u l y 2007$. 

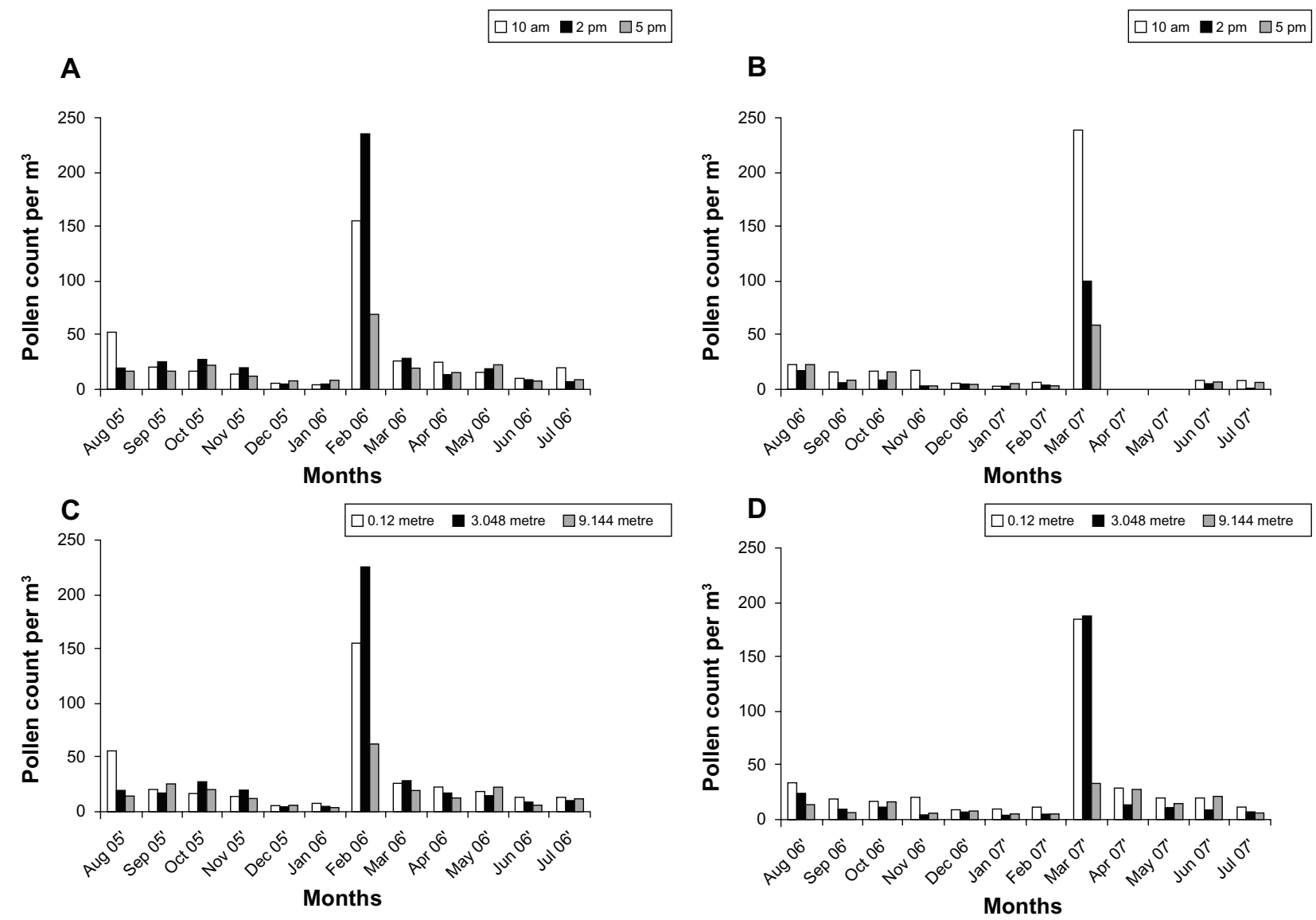

Figure 4 (A) Incidence of airborne pollen in Lucknow atmosphere with respect to diurnal variation (August 2005-July 2006). (B) Incidence of airborne pollen in Lucknow atmosphere with respect to diurnal variation (August 2006-July 2007). (C) Incidence of airborne pollen in Lucknow atmosphere with respect to different heights (August 2005-July 2006). (D) Incidence of airborne pollen in Lucknow atmosphere with respect to different heights (August 2006-July 2007).

pollen counts for 12 months of 2 successive years from 2005-2006 and 2006-2007, whereas correlation between pollen counts of some successive month were found to be significant (Figure 5B; Table 1A and B). The total pollen count was found to be influenced by the average temperature of a particular month, as the maximum pollen count was observed during an average temperature of $22^{\circ} \mathrm{C} \pm 0.2^{\circ} \mathrm{C}$. The correlation values were nonsignificant for these 2 years with regard to meteorological parameters. The data, however, revealed a positive correlation of relative humidity with pollen load for 2005-2006 only. The increase of one unit of relative humidity increased the pollen load by 0.118 units.

The study also revealed that the pollen peak was shifted from February (2005-2006) (154.67 pollen grains $/ \mathrm{m}^{3}$ ) to March (2006-2007) (133.70 pollen grains/ $\left.\mathrm{m}^{3}\right)$ as a result of abundant Holoptelea pollen, which contributed as high as $47 \%$ of the total airborne pollen of the year (Figure 2). The next most prevalent type was grass $(24 \%)$.

\section{Principal component analysis}

A score plot was made for the first two principal components (PC1 and $\mathrm{PC} 2)$ to interpret the classification of species according to their pollen grain counts of the 2 consecutive years examined (2005-2006 and 2006-2007) (Supplementary file 3, Sheets 1 and 2). Generally, a separation was observed among pollen grains according to pollen types; however, some samples did overlap. In particular, it was observed for Ixora spp. and families Bignoniaceae (2005-2006) (Figure 6A), Bombacaceae, Portulacaceae, and Ailanthus spp. overlapped during year 2006-2007 (Figure 6B). The first three PCs accounted for more than $84 \%$ of the variation, where PC1 showed $67 \%$, PC2 showed $10 \%$, and PC3 showed $7 \%$ of the variation related to the pollen for classification for the 2005-2006 data. However, for classification of the 2006-2007 data, the first three PCs accounted for more than $85 \%$ of the variation, where PC1 showed approximately 64\%, PC2 showed $11 \%$, and PC 3 showed $10 \%$ of the variation related to pollen. The eigenvectors for the first three PCs were used to develop 


\section{A}

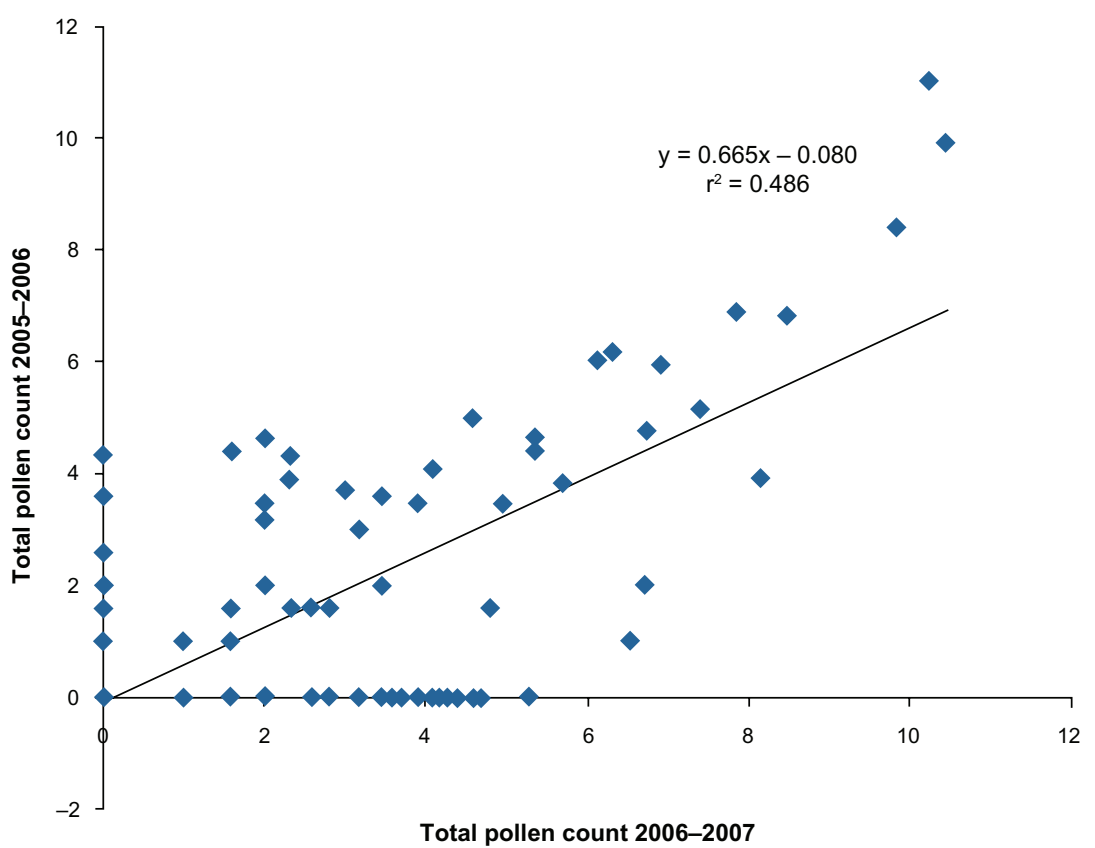

B
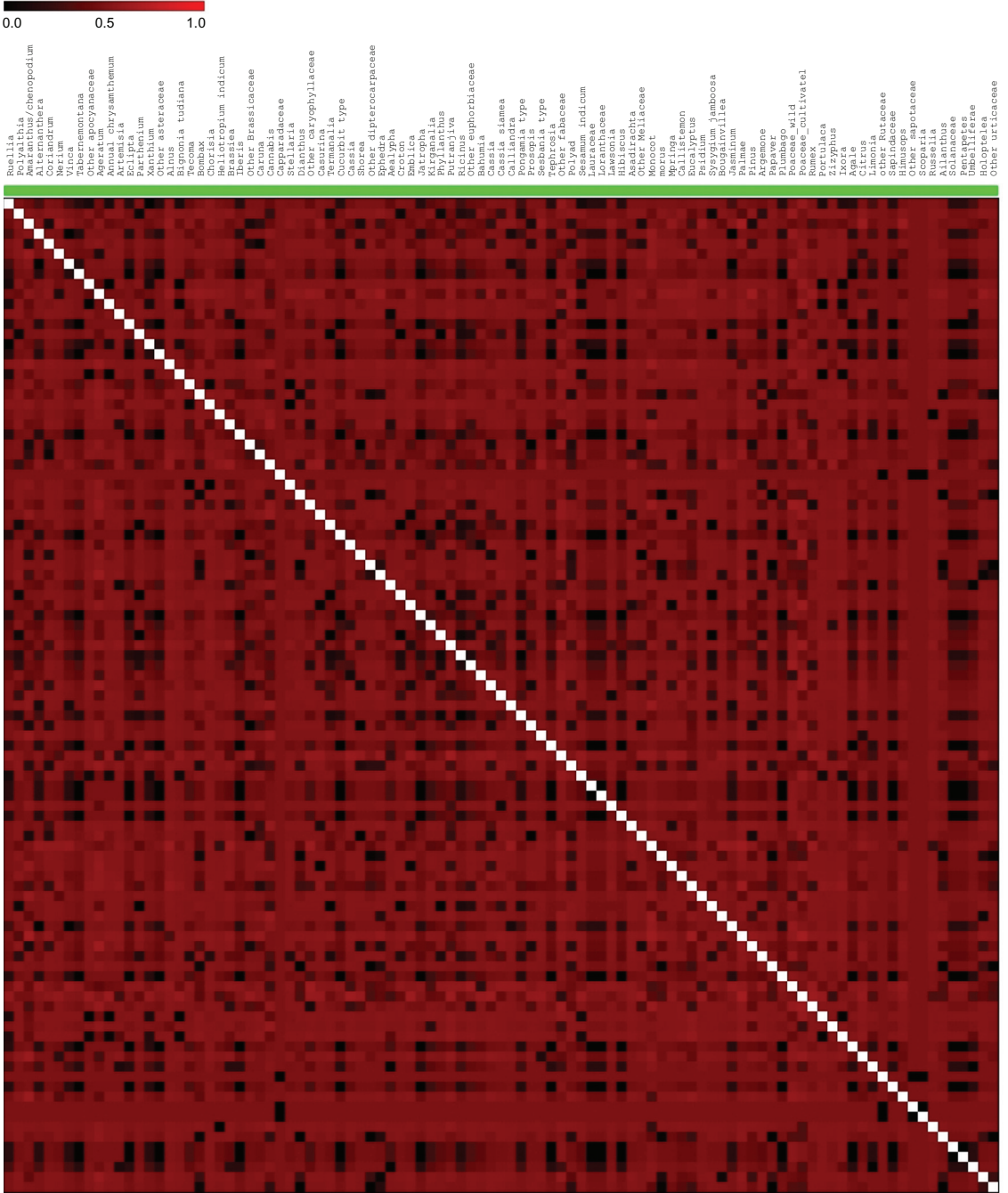

Figure 5 (A) The correlation coefficient for pollen count data for 12 months in two successive years, 2005-2006 and 2006-2007, using the linear equation $y=$ mx $+b$. (B) Correlation plot in between the total pollen counts ( $\log _{2}$ values) in two successive years, 2005-2006 and 2006-2007. 

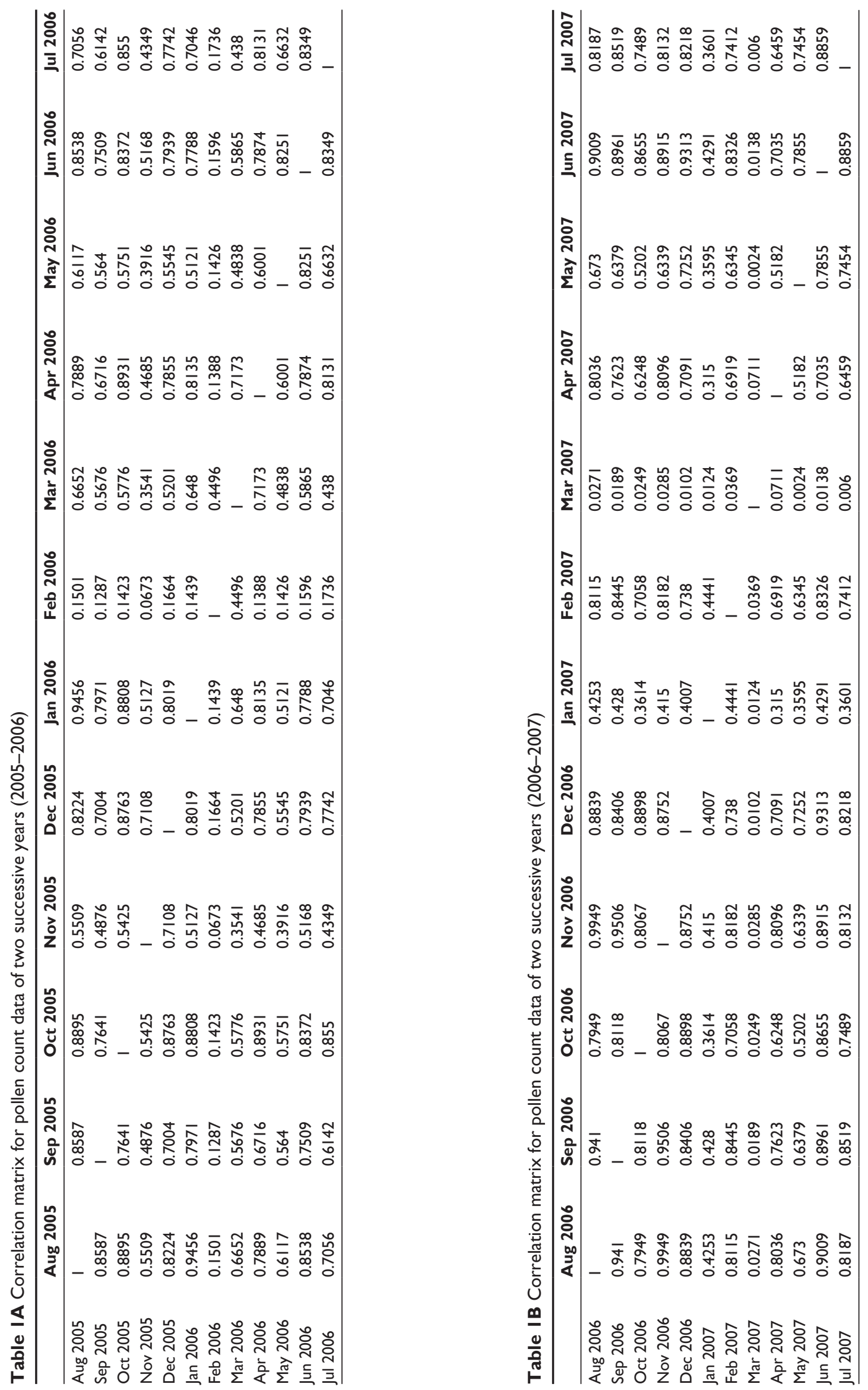


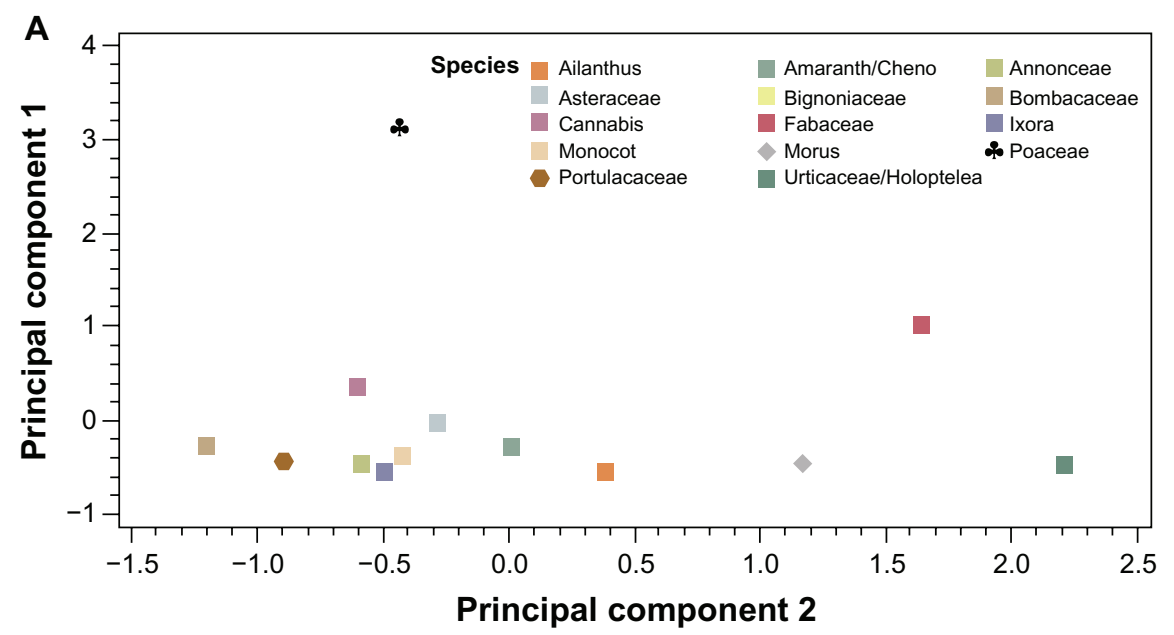

B

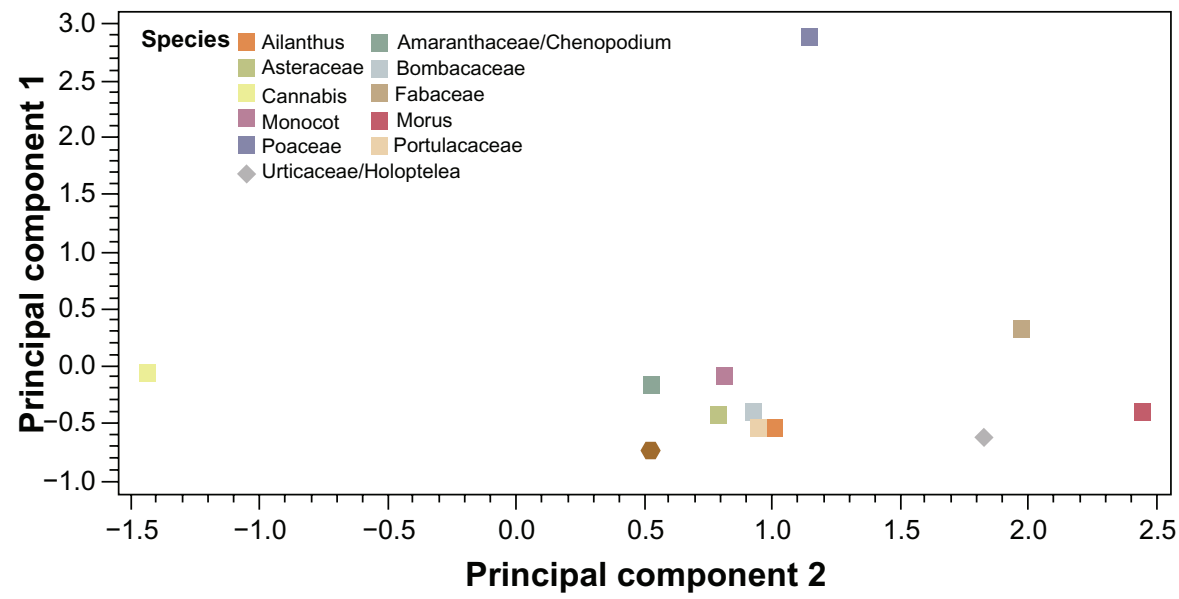

C

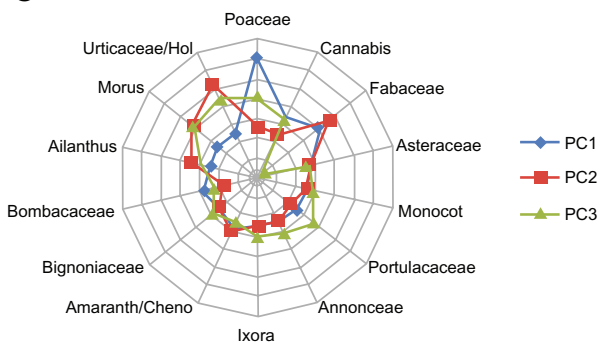

D

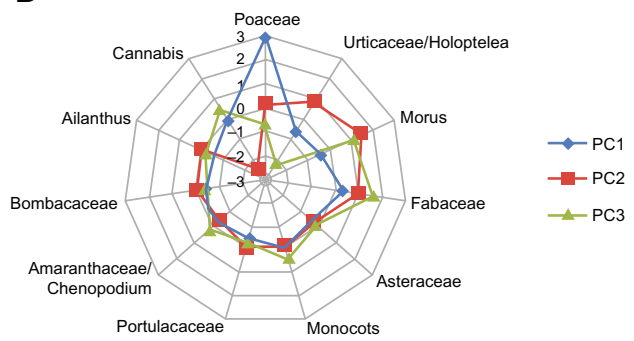

Figure 6 (A) PCA analysis for 12 months pollen grains for major 14 species of 2005-2006. (B) PCA analysis for 12 months pollen grains for major II species $2006-2007$. (C) Eigenvector for the first three principal components of pollen grains for 14 dominant species in 2005-2006. (D) Eigenvector for the first three principal components of pollen grains for II dominant species in 2006-2007.

Abbreviations: PCA, principle component analysis.

the PCA plot (radar plot) for both years. The highest eigenvector in $\mathrm{PC} 1$ was explained by the high percentage of pollen of Poaceae, in year 2005-2006, while the highest eigenvector in PC2 was explained by the highest percentage of pollen of Urticaceae/Holoptelea spp. and Fabaceae, and PC3 was explained by the highest percentage of pollen of Urticaceae/Holoptelea spp. and Portulacaceae. However, no clear separation was observed in the year 2005-2006 (Figure 6C). In 2006-2007, the highest eigenvector in PC1 was explained by the high percentage of pollen of Poaceae, while that in PC2 was explained by the highest percentage of pollen of Morus spp. and in PC3 by the highest percentage of pollen of Fabaceae, Morus spp. and Cannabis spp. (Figure 6D), although no clear separation was observed. 
The PCA scores were related to total pollen counts in different months of the year.

\section{Diurnal and vertical variation}

Diurnal monitoring of the airborne pollen revealed that during 2005-2006, the concentration of airborne pollen was highest around 2 pm in February 2006 (235.5 pollen grains $/ \mathrm{m}^{3}$ ) (Figure 4A), while during 2006-2007, the maximum concentration was noted at 10 am in March (240.32 pollen grains $/ \mathrm{m}^{3}$ ) (Figure 4B). It was found that during the second pollen season, ie, autumn, pollen accumulation was higher at $10 \mathrm{am}\left(53.18\right.$ pollen grains $\left./ \mathrm{m}^{3}\right)$ than in August 2005 (first year) (Figure 4A) than in the afternoon, while it was nearly the same in the morning $(23.33$ pollen grains $\left./ \mathrm{m}^{3}\right)$ and afternoon (24.13 pollen grains $/ \mathrm{m}^{3}$ ) in August 2006 (Figure 4B). The vertical profile indicated that accumulation of pollen was maximum at the $3.048 \mathrm{~m}$ height (224.29 pollen grains $/ \mathrm{m}^{3}$ ) during February 2006 (Figure 4C), while in the consecutive year, nearly the same concentration was noted (184.6 pollen grains $\left./ \mathrm{m}^{3}\right)$ for $(185$ pollen grains $/ \mathrm{m}^{3}$ ) both the $0.12 \mathrm{~m}$ height and $3.048 \mathrm{~m}$ height (Figure 4D). The data revealed the pollen concentration at $0.12 \mathrm{~m}$ was maximum during the second pollen peak of

A
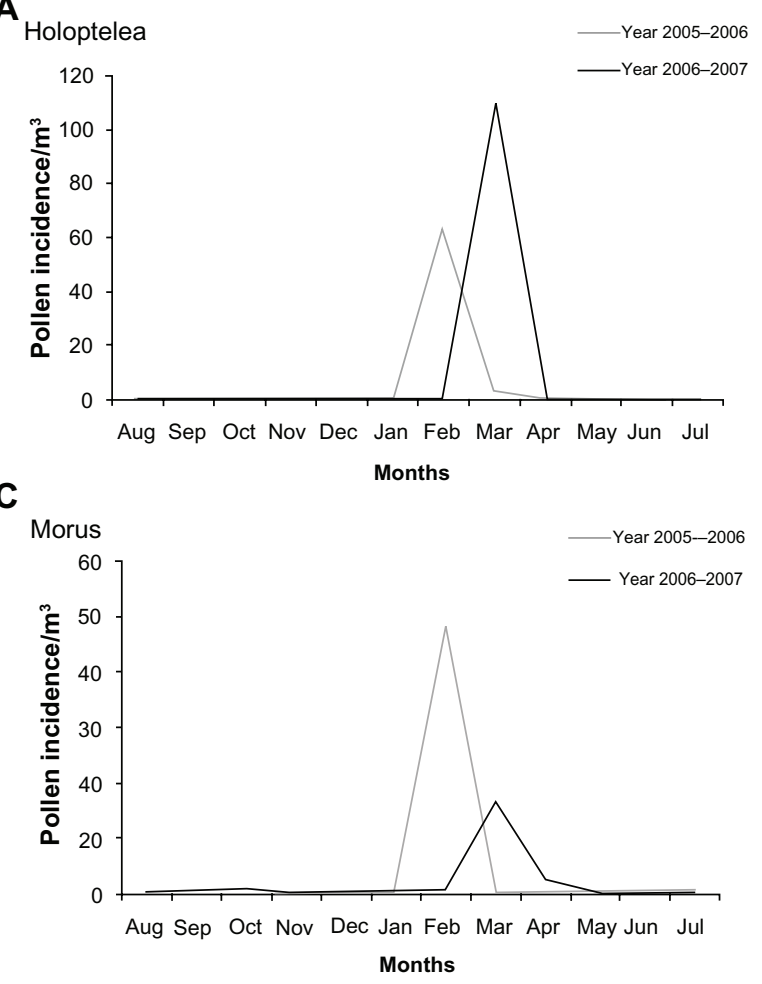

both the years, ie, August 2005 (55.08 pollen grains $/ \mathrm{m}^{3}$ ) (Figure 4C) and August, 2006 (30.95 pollen grains $/ \mathrm{m}^{3}$ ) (Figure 4D).

\section{Pollen distribution patterns}

In both years, spring was the major pollen season due to high incidence of anemophilous trees such as Holoptelea, Ailanthus, and Morus. (Figure 7A-C). It was noticed that February 2006 was the most pollen rich-month due to combined load of Morus spp. and Holoptelea spp. pollen. However, the lower pollen incidence of Morus in February 2007 and profuse flowering in Holoptelea spp. in March 2007 resulted in a shift of the pollen peak to March in the consecutive year. Analysis of the data also revealed that abundant flowering in Morus spp., which has an afternoon pattern of flowering, resulted in a high concentration of pollen around 2 pm in February 2006 (Figure 4A), while in next year profuse blooming of $\mathrm{Hol}$ optelea spp. with a morning pattern of anthesis caused a high pollen concentration around 10 am in March 2007 (Figure 4B). The pollen load of autumn (second pollen peak) mainly consisted of grasses (Figure 7D) and herbs, flowering after the rainy season and as most of the grasses

B
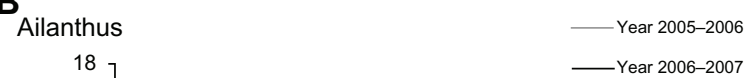

Poaceace — Year 2005-2006
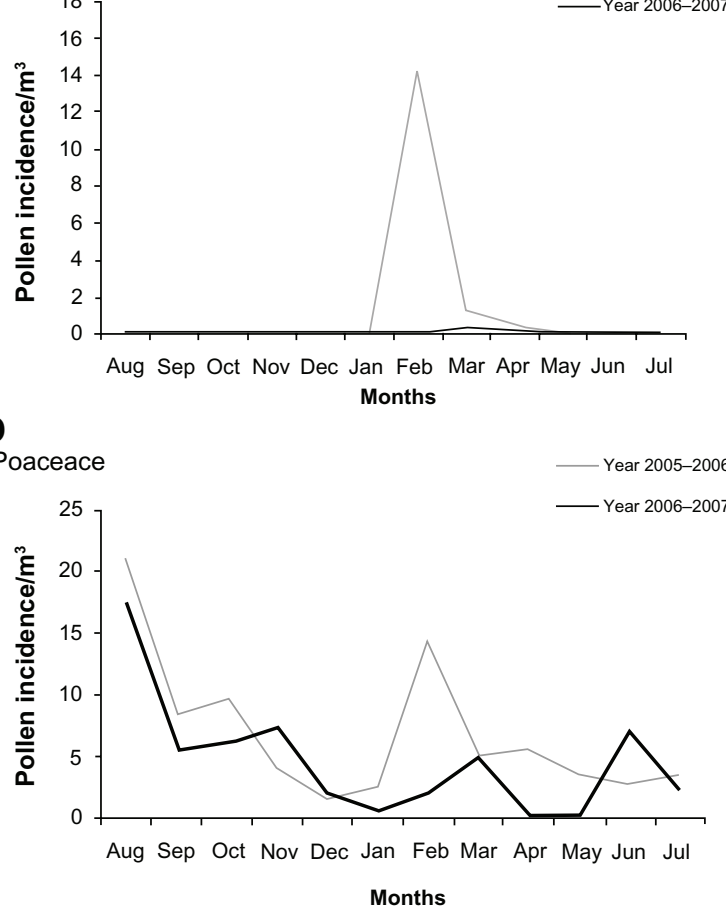

Figure 7 (A-D) Incidence of major airborne pollen in Lucknow atmosphere during 2005-2007. 


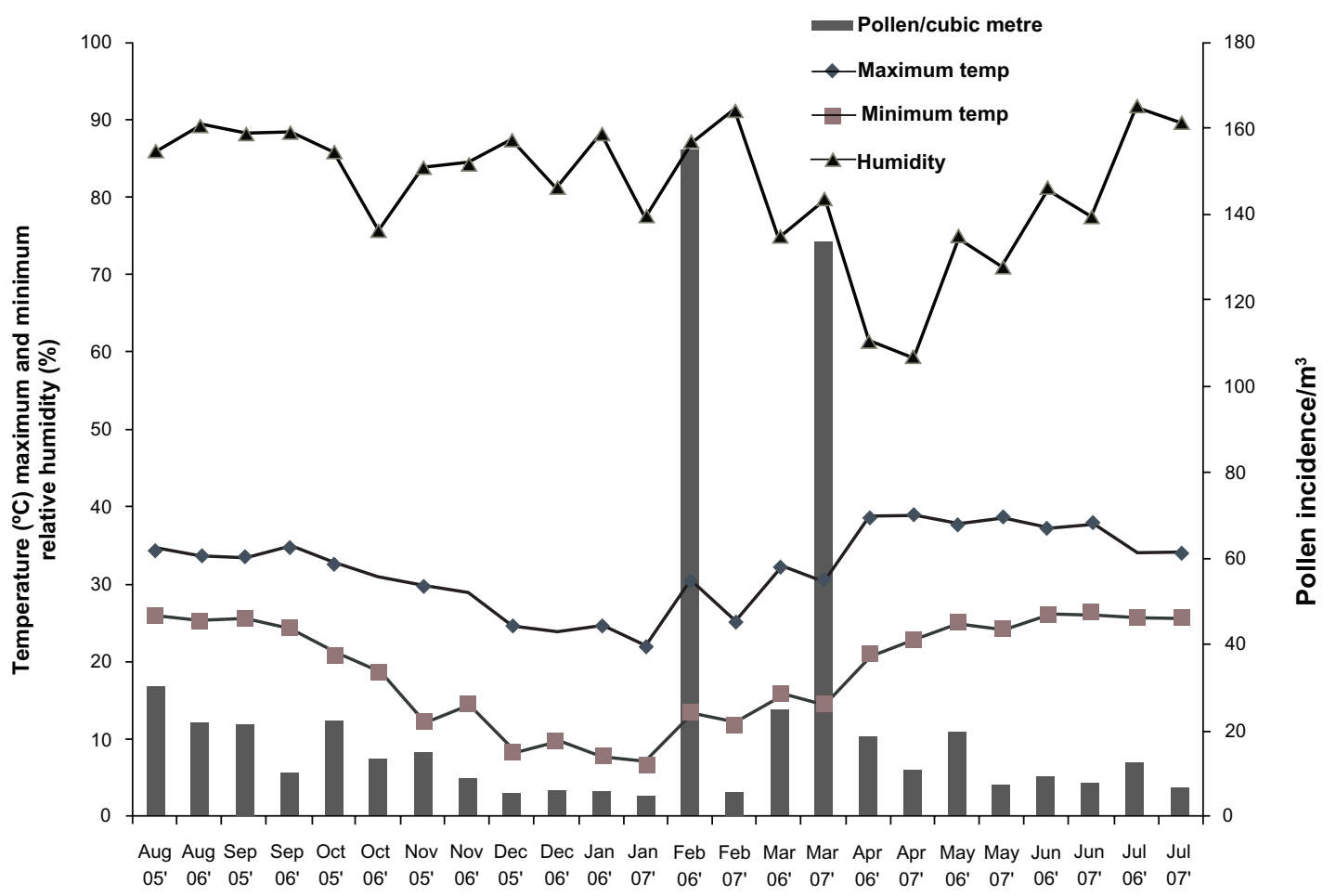

Figure 8 Incidence of airborne pollen in Lucknow atmosphere and prevailing meteorological parameters from August 2005-July 2006 and August 2006-July 2007.

open during forenoon, the pollen concentration reached a maximum at 10 am during both years. The pollen grains of some herbs, however, contributed to afternoon pollen catch (Figure 4A and B). The vertical profile of both years showed a maximum concentration at the ground level, which was a result of accumulation of grass and herb pollen at low levels (Figure 4C and D). The meteorological data indicated many rainy days in February 2007, which may have contributed to the unusually low pollen catch during this month. Atmospheric pollen incidence in the prevailing meteorological conditions, monthly averages of overall temperature, and $\mathrm{RH}$ in the study area during the two sampling years (2005-2007) are presented in Figure 8. As shown in the figure, temperature levels were higher in the months between April and July and RH levels were highest in the months of July 2006 and February 2007, where these values were more than $90 \%$ compared to the other months of both sampling years.

\section{Discussion}

The present study reveals very useful information regarding the current scenario of atmospheric pollen grains of Lucknow, along with diurnal, seasonal and annual variation. The data generated from the two-year volumetric survey indicated that qualitative and quantitative concentration of aerospora not only differs seasonally or annually, but also differs diurnally and to some extent vertically. This may be influenced by a number of factors, including meteorological parameters. The survey showed that the airborne pollen incidence of Lucknow was greater in the year 2005-2006 for both pollen types and frequencies than in 2006-2007.

In terms of pollen load, spring was the peak season of both years. While in the first year, February showed the highest pollen incidence, in the next year, the peak shifted to March (Figure 7). Flowering of anemophilous trees created high pollen incidence during spring, many of which were allergenic and significant. ${ }^{26,27}$ Variation of total pollen content occurred due to distinct inter-annual species specific fluctuation of pollen incidence. ${ }^{28}$ Analysis of the data showed that during spring of 2005-2006, pollen concentration was much higher due to high pollen incidence of a number of tree species, eg, Morus, Ailanthus and also many species of family Fabaceae, which starts flowering in February. However, in the subsequent year, the pollen incidence of these species was much lower in February as compared to Holoptelea spp. (45\%), which flowers mainly in March. Pollen production of certain trees differing from another in a given year may be due to the physiological biorhythm of the particular tree species. 
This type of variation in pollen incidence among tree species may influence vertical pollen concentration near the site of the pollen source as has been revealed in the present study. The data shows dominance of pollen grains of Morus spp., Ailanthus spp., and Holoptelea spp. along with the tree species of family Fabaceae, which cumulatively affected maximum pollen concentration at a height of $3.048 \mathrm{~m}$ during the spring of 2006.

In the next year (2006-2007), nearly equal pollen concentrations at ground level and a height of $3.048 \mathrm{~m}$ were noted; it was found that the pollen of Holoptelea appeared at both the levels in large amounts. It was also evident from the study that diurnal variability of pollen concentration is significantly related to the pattern of pollen emission and incidence of major pollen contributor of the season. Yang et al also observed that the diurnal pattern was irregular in some plants which produced a smaller pollen quantity than those which produced large amounts of pollen. ${ }^{29}$ Therefore, the afternoon pattern of Morus pollen showed the highest concentration at $2 \mathrm{pm}$ in 2006 and the morning pattern of Holoptelea showed maximum pollen accumulation at $10 \mathrm{am}$ in the spring of 2007. These findings provide important information for both patients and physicians for managing pollen allergy, as both the taxa have a hazardous effect on susceptible persons. ${ }^{27}$ The second pollen season (autumn), was represented mainly by pollen grains of grasses and herbaceous taxa including Ageratum, Cannabis, Amaranthus (Amaranth), and Chenopodium (Chenopods), which showed more stable airborne incidence in comparison to trees during the two-year survey. Both years' pollen peak was in August, with diurnal periodicity at $10 \mathrm{am}$ in first year and at $10 \mathrm{am}$ and $5 \mathrm{pm}$ in the second year, as some grasses and herbs have late morning or afternoon anthesis.

The relationship between meteorological factors and airborne pollen counts has been studied and discussed by various authors, and interesting interpretations have been made. ${ }^{30-33}$ Teranishi et al, formulated an association of total pollen count increase in accordance with an elevated average temperature of the previous year. ${ }^{34}$ As in the present case, the total pollen count may be influenced by the average temperature $\left(22^{\circ} \mathrm{C} \pm 0.2^{\circ} \mathrm{C}\right)$ of a particular month. This is indicated by a shift in the pollen peak for maximum pollen count from February (2005-2006) to March (2006-2007). Alwadie clearly demonstrated that daily mean and maximum temperature, daily temperature fluctuation, and the number of hours of sunshine have a significant positive effect on pollen count. ${ }^{5}$ However, the amount of precipitation and RH negatively influence pollen count. Thus, phenology may not be the only factor influencing the seasonal variation in the total pollen count since this phenomenon is known to be very sensitive to even minor variations in climate, particularly temperature. In the present survey, it was found that the month of July (rainy season) had maximum average RH (91.89\%) in 2006, but in 2007, the maximum RH was noted in February (91.29\%) due to unusual rain in the early spring, during which a low pollen concentration was observed. Thus, it can be inferred that atmospheric pollen incidence may be negatively correlated with high precipitation and number of rainy days in the month. This fact was also reported by Smart et al, Fehér and Járai-Komlódi, and Alwadie. 5,35,36

The above study showed that aerospora of any given region is a true depiction of the local vegetation, though it is also significantly influenced by various biotic and abiotic factors. Despite the impact of such factors which emerge with the course of time, it has been noted that the prevalent airborne taxa of a certain region primarily remains the same, with few noticeable variations. Studies from previous aerobiological surveys have shown that the prevailing aerospora of Lucknow is predominated by a few wind-pollinated taxa, though variations in their quantitative load cannot be ruled out. ${ }^{17,18,20,26}$ Thus, the results of all aerobiological surveys assist in characterizing the dominant aerospora of the region in question. However, seasonal periodicity provides important information for diagnosing allergenic pollen grains causing allergenic symptoms in susceptible persons. The present survey offers additional information regarding volumetric data, which is more accurate for measuring the quantitative concentration of pollen in atmosphere. The current investigation also provides intricate information regarding diurnal and altitudinal concentration, which would be of great help for the susceptible persons to avoid the hazardous exposure and the physician to give proper treatment. Earlier surveys, however provided only seasonal or month-wise concentrations of airborne pollen. ${ }^{17,18,20,26}$ Avoiding allergenic pollen is the best method of taking precaution, but this may not be easy for an active person to confine himself indoors for an entire season. The findings of the present survey provide information about the specific period of the day when the outside atmosphere is loaded with maximum concentrations of particular offending pollens; consideration of this information would make it easier for a person to avoid harmful exposure. The detailed data, providing fluctuation in pollen incidence of different species, may be linked with various factors such as pollen production, comparative dominance 
of specific taxa in certain year due to physiological factors, and, of course, various prevailing meteorological conditions which offer prerequisites for in-depth study of environment and ecology. ${ }^{2}$

\section{Conclusion}

The study area is the host to a variety of trees, weeds, and grasses that produce copious amounts of pollen grains. Our study found that phenology alone cannot be considered as the sole factor influencing seasonal variation in total pollen count; instead, meteorological factors (temperature and $\mathrm{RH}$ ), also play a governing role in pollination phenology. Our results showed a positive effect of temperature and negative effect of rain fall, which should be taken into account for a more reliable forecast of both the beginning and main pollen peak emission rate. Early flowering and an average temperature of $22^{\circ} \mathrm{C} \pm 0.2^{\circ} \mathrm{C}$ are factors that positively influence the final yield. A more complete examination of the relationship among meteorological parameters, significant weather events, and year-to-year variation in daily pollen levels was well beyond the scope of this investigation. Further studies are needed to better elucidate the complexities of this relationship and facilitate the development of a predictive model that may enable the forecasting of daily pollen levels, which can be used in allergy prevention centers to predict high-risk periods. The knowledge gained would be invaluable for both the allergy practitioners and the atopic patients.

\section{Acknowledgments}

The director of NBRI is acknowledged for the use of its infrastructural facilities.

\section{Disclosure}

The authors report no conflicts of interest in this work.

\section{References}

1. Ziska LH, Epestein PR, Rogers CA. Climate change, aerobiology, and public health in the Northeast United States. Mitig Adapt Strat Glob Change. 2008;13(5):607-613.

2. Khanduri VP. Variation in anthesis and pollen production in plants. American-Eurasian J Agric and Environ Sci. 2011;11(6):834-839.

3. Frenz DA, Murray LW. An atmospheric pollen survey conducted during the winter in Minneapolis, Minnesota, USA. Grana. 1997;36: 245-248.

4. Dvorin DJ, Lee JJ, Belecaneth GA, Goldstein MF, Dunsky EH. A comparative, volumetric survey of airborne pollen in Philadelphia, Pennsylvania (1991-1997) and Cherry Hill, New Jersey (1995-1997). Ann Allergy Asthma Immunol. 2001;87(5):394-404.

5. Alwadie HM. Pollen concentration in the atmosphere of Abha City, Saudi Arabia and its relationship with meteorological parameters. J Appl Sci. 2008;8:842-847.
6. Liu ZG, Song JJ, Kong XL. A study on pollen allergens in China. Biomed Environ Sci. 2010;23(4):319-322.

7. Murray MG, Galan C, Villamil CB. Airborne pollen in Bahia Blanca, Argentina: Seasonal distribution of pollen types. Aerobiologia. 2010;26(3):195-207.

8. Çeter T, Pinar NM, Güney K, Yildiz A, Aşcı B, Smith M. A 2-year aeropalynological survey of allergenic pollen in the atmosphere of Kastamonu, Turkey. Aerobiologia. 2012;28(3):355-366.

9. Melgar M, Trigo MM, Recio M, Docampo S, García-Sánchez J, Cabezudo B. Atmospheric pollen dynamics in Münster, northwestern Germany: a three-year study (2004-2006). Aerobiologia. 2012:1-12.

10. Singh AB, Babu CR. Survey of atmospheric pollen allergens in Delhi: seasonal periodicity. Annals Allergy. 1982;48(2):115-122.

11. Mandal J, Chakraborty P, Roy I, Chatterjee S, Gupta-Bhattacharya S. Prevalence of allergenic pollen grains in the aerosol of the city of Calcutta, India: a two year study. Aerobiologia. 2008;24(3): 151-164.

12. Sahney M, Chaurasia S. Seasonal variations of airborne pollen in Allahabad, India. Ann Agric Environ Med. 2008;15(2):287-293.

13. Shukla S, Shukla RV.A quantitative survey of pollen flora in atmosphere of Korba-Chhattisgarh, India. Int J Bot. 2010;6(4):449-455.

14. Nayar TS, Jothish PS. An assessment of the air quality in indoor and outdoor air with reference to fungal spores and pollen grains in four working environments in Kerala, India. Aerobiologia. 2012 (DOI 10.1007/s10453-012-9269-8).

15. Ariano R, Canonica GW, Passalacqua G. Possible role of climate changes in variations in pollen seasons and allergic sensitizations during 27 years. Ann Allergy Asthma Immunol. 2010;104(3):215-222.

16. Puc M, Bosiacka B. Effects of Meteorological Factors and Air Pollution on Urban Pollen Concentrations. Pol J of Environ Stud. 2011;20(3):611-618.

17. Khandelwal A. Aerobiology: Aspects and prospects. The Paleobotanist. 2008;57:251-255.

18. Lakhanpal RN, Nair PKK. Survey of atmospheric pollen of Lucknow. J Sci Indust Res. 1958;17(e):80-87.

19. Mittre V, Khandelwal A. Airborne pollen grains and fungal spores at Lucknow during 1969-1970. Paleobotanist. 1973;22:177-185.

20. Chaturvedi M, Datta K, Nair PKK. A fresh survey of airborne pollen at Lucknow. J Palynology (G.Thanikaimoni Memorial Volume). 1987-1988;23-24:117-143.

21. Khandelwal A. Survey of aerospora by Rotorod Sampler in Lucknow, India: qualitative and quantitative assessment. Aerobiologia. 2001;17: $77-83$.

22. Erdtman G. Pollen morphology and Plant Taxonomy. Angiosperms. E. J. Brill Publishing, Lieden, The Netherlands; 1983:553.

23. Nair PKK. Pollen morphology of angiosperms. A historical and phylogenetic study. National Botanical Gardens, Lucknow. Scholar Publishing House, India; 1970.

24. Naes T, Isaksson T, Fearn T, Davies T. A user-friendly guide to multivariate calibration and classification. NIR Publications, Chichester, UK; 2002:344.

25. Chao HJ, Schwartz J, Milton DK, Burge HA. Populations and determinants of airborne fungi in large office buildings. Environ Health Perspect. 2002;110(8):777-782.

26. Agnihotri MS, Singh AB. Observations in pollinosis in Lucknow with special reference to offending factors. Aspects Allergy Appl Immunol. 1971;5:135-140.

27. Singh AB, Kumar P. Common environmental allergens causing respiratory allergy in India. Indian J Pediatr. 2002;69(3):245-250.

28. Singh AB, Pandit T, Dahiya P. Changes in airborne pollen concentrations in Delhi, India. Grana. 2003;42:168-177.

29. Yang YL, Huang TC, Chen SH. Diurnal variations of airborne pollen and pores in Taipei City, Taiwan. Taiwania. 2003;48:168-179.

30. Galán C, Alcázar P, Cariñanos P, García-Mozo, H, Domínguez E. Meteorological factors affecting daily Urticaceae pollen counts in southwest Spain. Int J Biometeorol. 2000;43(4):191-195. 
31. Gioulekas D, Balafoutis C, Damialis A, Papakosta D, Gioulekas G, Patakas D. Fifteen years' record of airborne allergenic pollen and meteorological parameters in Thessaloniki, Greece. Int J Biometeorol. 2004;48(3):128-136.

32. Stennett PJ, Beggs PJ. Pollen in the atmosphere of Sydney, Australia, and relationships with meteorological parameters. Grana. 2004;43:209-216.

33. Sousa SIV, Martins FG, Pereira MC, et al. Influence of atmospheric ozone, PM10 and meteorological factors on the concentration of airborne pollen and fungal spores. Atmos Environ. 2008;42:7452-7464.
34. Teranishi H, Kenda Y, Katoh T, Kasuya M, Oura E, Taira H. Possible role of climate change in the pollen scatter of Japanese cedar Cryptomeria japonica in Japan. Climate Research. 2000;14:65-70.

35. Smart JJ, Tuddenham WG, Knox RB. Aerobiology of grass pollen in the city atmosphere of Melbourne: Effects of weather parameters and pollen sources. Austral J Bot. 1979;27:333-342.

36. Fehér Z, Járai-Komlódi M. A new weather factor predicting airborne pollen concentration: Péczely's macrosynoptic weather types. Aerobiologia. 1998;14:171-177. 


\section{Supplementary files}

File I

\begin{tabular}{|c|c|c|c|c|c|c|c|c|c|c|c|c|c|}
\hline Species & 5-Aug & 6-Aug & 5-Sep & 6-Sep & 5-Oct & 6-Oct & 5-Nov & 6-Nov & 5-Dec & 6-Dec & 6-Jan & 7-Jan & 6-Feb \\
\hline Ruellia & 0 & 0 & 2 & 0 & 0 & 0 & 0 & 0 & 0 & 0 & 0 & 0 & 0 \\
\hline Polyalthia & 0 & 0 & 0 & 0 & 0 & 0 & 0 & 0 & 0 & 0 & 0 & 0 & 0 \\
\hline Amaranthus/Chenopodium & 14 & I & 13 & 6 & 12 & II & 4 & 0 & 3 & 2 & 1 & 12 & 7 \\
\hline Alternanthera & 0 & 0 & 0 & 0 & 0 & 0 & 0 & 0 & 2 & 0 & I & 0 & 0 \\
\hline Coriandrum & 0 & 0 & 0 & 0 & 0 & 0 & 0 & 0 & 0 & 0 & 0 & 0 & 0 \\
\hline Nerium & 0 & 4 & 0 & 0 & 0 & 0 & 0 & 0 & 0 & 0 & 0 & 0 & 0 \\
\hline Vinca & 0 & 0 & 0 & 0 & 0 & 0 & 0 & 0 & 2 & 0 & 0 & 0 & 0 \\
\hline Tabernemontana & 0 & 0 & 0 & 0 & 1 & 0 & 0 & 0 & 0 & 0 & 0 & 0 & 0 \\
\hline Other Apocyanaceae & 0 & 0 & 8 & 0 & 1 & I & 1 & 0 & 0 & 0 & 0 & 0 & 0 \\
\hline Ageratum & 19 & 5 & 9 & 2 & 9 & I & 0 & 0 & 5 & 2 & 2 & 0 & 2 \\
\hline Annual Chrysanthemum & 0 & 0 & 12 & 0 & 0 & 0 & 2 & 0 & I & 0 & 2 & 0 & 0 \\
\hline Artemisia & 0 & 0 & 0 & 0 & 9 & I & 3 & 0 & 0 & 0 & I & 0 & 0 \\
\hline Eclipta & 1 & I & 0 & 0 & 0 & 0 & 0 & 0 & 0 & 0 & 0 & 0 & 0 \\
\hline Parthenium & 0 & 0 & 0 & 0 & 0 & 0 & 0 & 0 & 0 & 0 & 0 & 0 & 0 \\
\hline Xanthium & 0 & 0 & 2 & 0 & 0 & 0 & 0 & 0 & 0 & 0 & 0 & 0 & 0 \\
\hline Other Asteraceae & 1 & 0 & 0 & 0 & 0 & 0 & 1 & I & 0 & 0 & 0 & 0 & 0 \\
\hline Alnus & 0 & 0 & 0 & I & I & 2 & 2 & 2 & I & 6 & 0 & 0 & 0 \\
\hline Bignonia tudiana & 0 & 0 & 17 & 0 & 0 & 0 & 0 & 0 & 0 & 0 & 0 & 0 & 0 \\
\hline Tecoma & 0 & 0 & 0 & 1 & 0 & 0 & 3 & 0 & 0 & 0 & 0 & 0 & 0 \\
\hline Bombax & 1 & 0 & 0 & 0 & 0 & 0 & 0 & 2 & 0 & 0 & 0 & 0 & 10 \\
\hline Chorisia & 0 & 2 & 0 & 0 & 4 & 0 & 91 & 0 & 10 & 0 & 0 & 0 & 0 \\
\hline Heliotropium indicum & 0 & 0 & 0 & 6 & 0 & 0 & 0 & 0 & 0 & 0 & 0 & 0 & I \\
\hline Brassica & 0 & 0 & 0 & 0 & 3 & 0 & 2 & 0 & 0 & 0 & 0 & 3 & 0 \\
\hline Iberis & 0 & 0 & 0 & 0 & 0 & 0 & 0 & 0 & 0 & I & 0 & 0 & 0 \\
\hline Other Brassicaceae & 0 & 0 & 0 & 0 & 0 & 0 & 0 & 0 & 0 & I & 0 & 0 & 0 \\
\hline Canna & 0 & 2 & 0 & 0 & 0 & 0 & 0 & 0 & 0 & 0 & 0 & 4 & 2 \\
\hline Cannabis & 53 & 20 & 39 & 6 & 9 & 3 & 19 & 0 & 4 & 10 & 0 & 3 & 74 \\
\hline Capparadaceae & 0 & 0 & 0 & 0 & 0 & 0 & 0 & 0 & 0 & 0 & 0 & 0 & 0 \\
\hline Stellaria & 0 & 0 & 0 & 0 & 0 & 0 & 7 & 0 & 0 & 0 & 0 & 0 & 0 \\
\hline Dianthus & 0 & 0 & 0 & 0 & 0 & 0 & 0 & 0 & 0 & 0 & 0 & 0 & 4 \\
\hline Other Caryophyllaceae & 0 & 0 & 0 & 0 & 1 & 0 & 2 & 0 & 0 & 0 & 0 & 3 & 0 \\
\hline Casurina & 0 & 0 & 0 & 0 & 0 & 0 & 0 & 0 & 0 & 0 & 0 & 0 & 0 \\
\hline Termanalia & 2 & 0 & 0 & 0 & 0 & 0 & 2 & 0 & 0 & 0 & 0 & 0 & 0 \\
\hline Cucurbit type & 0 & 0 & 0 & I & I & 0 & 0 & 0 & 0 & 0 & 0 & 0 & 0 \\
\hline Cyperaceae & 4 & 0 & 0 & 0 & 0 & 0 & 0 & 0 & 0 & I & 0 & 3 & 0 \\
\hline Shorea & 0 & 0 & 0 & 0 & 0 & 0 & 0 & 0 & 0 & 0 & 0 & 0 & 0 \\
\hline Other Dipterocarpaceae & 0 & 0 & 0 & 0 & 0 & 0 & 0 & 0 & 0 & 0 & 0 & 0 & 4 \\
\hline Ephedra & 0 & 0 & 0 & 0 & 0 & 0 & 0 & 0 & 0 & 0 & 0 & 0 & 3 \\
\hline Acalypha & 0 & 0 & 0 & 0 & 3 & 0 & 0 & 0 & 0 & 0 & 0 & 0 & 0 \\
\hline Croton & 0 & 0 & 0 & 0 & 0 & 0 & 0 & 0 & 0 & 0 & 0 & 0 & 0 \\
\hline Emblica & 3 & 0 & 0 & 0 & 0 & 0 & 0 & 0 & 0 & 0 & 0 & 0 & I \\
\hline Jatropha & 0 & 0 & 0 & 0 & 1 & 0 & 0 & 0 & 0 & 0 & 0 & 0 & 0 \\
\hline Kirganalia & 2 & 0 & 0 & 0 & 0 & 2 & 0 & 0 & 0 & 0 & 0 & 0 & 0 \\
\hline Phyllanthus & 1 & 0 & 0 & 0 & 0 & 0 & 0 & 0 & 0 & 0 & 0 & 0 & 0 \\
\hline Putranjiva & 0 & I & 0 & 0 & 0 & 0 & 0 & 3 & 0 & 0 & 0 & 0 & 2 \\
\hline Ricinus & 0 & 0 & 0 & 0 & 0 & 0 & 0 & 0 & 0 & I & 0 & 0 & 0 \\
\hline Other Euphorbiaceae & 0 & 0 & 0 & 0 & 0 & 0 & I & 0 & I & 0 & 0 & 3 & 0 \\
\hline Bahunia & 4 & 0 & 0 & 0 & 0 & 0 & 0 & 0 & 0 & 0 & 0 & 0 & 0 \\
\hline Cassia & 0 & 0 & 0 & 0 & 3 & 0 & 3 & 0 & 0 & 6 & 0 & 0 & 0 \\
\hline Cassia siamea & 0 & 0 & 0 & 0 & 0 & 0 & 0 & 0 & 0 & 0 & 0 & 0 & 0 \\
\hline Calliandra & 0 & 0 & 0 & 0 & 0 & 0 & 0 & 0 & II & 0 & 0 & 0 & 0 \\
\hline Pongamia type & 0 & 0 & 0 & 0 & 0 & 0 & 0 & I & 0 & 0 & I & 0 & 0 \\
\hline Prosopis & 0 & 0 & 0 & 0 & 0 & 0 & 0 & 0 & 0 & 0 & 0 & 0 & 0 \\
\hline Sesbania type & 0 & 0 & 0 & 0 & 0 & 0 & 0 & 0 & 0 & 0 & 3 & 0 & 0 \\
\hline
\end{tabular}




\begin{tabular}{|c|c|c|c|c|c|c|c|c|c|c|c|c|}
\hline 7-Feb & 6-Mar & 7-Mar & 6-Apr & 7-Apr & 6-May & 7-May & 6-Jun & 7-Jun & 6-Jul & 7-Jul & $\begin{array}{l}\text { Total } \\
\text { pollen_Ist year }\end{array}$ & $\begin{array}{l}\text { Total } \\
\text { pollen_2nd year }\end{array}$ \\
\hline 0 & 0 & 0 & 0 & 0 & 0 & 0 & 0 & 0 & 0 & 0 & 2 & 0 \\
\hline 0 & 0 & 0 & 0 & 3 & 36 & 18 & 5 & 0 & 0 & 0 & $4 I$ & 21 \\
\hline 5 & 37 & 16 & 18 & 2 & 8 & 3 & 3 & 3 & I & 0 & $|2|$ & 61 \\
\hline 0 & 0 & 0 & 0 & 0 & 0 & 0 & 0 & 0 & 0 & 0 & 3 & 0 \\
\hline 0 & 2 & 0 & 2 & 0 & 0 & 0 & 0 & 0 & 0 & 0 & 4 & 0 \\
\hline 0 & 0 & 0 & 0 & 0 & 0 & 0 & 0 & 0 & II & 0 & 11 & 4 \\
\hline 0 & 0 & 0 & 0 & 0 & 0 & 0 & 0 & 0 & 0 & 0 & 2 & 0 \\
\hline 0 & 0 & 0 & 0 & 0 & 0 & 0 & 0 & 0 & 0 & 0 & 1 & 0 \\
\hline 0 & 0 & 0 & 0 & 0 & 0 & 0 & 0 & 0 & 2 & 0 & 12 & 1 \\
\hline 0 & 0 & 1 & 6 & I & 12 & 3 & 13 & 8 & 30 & 4 & 107 & 27 \\
\hline 0 & 2 & 0 & 0 & 0 & 0 & 0 & 0 & 0 & 0 & 0 & 19 & 0 \\
\hline 0 & 0 & 0 & 0 & 0 & 0 & 0 & 0 & 0 & 0 & 0 & 13 & I \\
\hline 0 & 0 & 0 & 0 & 0 & 0 & 0 & 0 & 0 & 0 & 0 & 1 & I \\
\hline 0 & 0 & 0 & 0 & 0 & 3 & 0 & 0 & 0 & 0 & 0 & 3 & 0 \\
\hline 0 & 0 & 0 & 0 & 0 & 0 & 0 & 0 & 0 & 0 & 0 & 2 & 0 \\
\hline 0 & 0 & 0 & 0 & 0 & 0 & 0 & 0 & 0 & 0 & 0 & 2 & 1 \\
\hline 0 & 0 & 0 & 0 & 0 & 0 & 0 & 0 & 0 & 0 & 0 & 4 & 11 \\
\hline 0 & 0 & 0 & 0 & 0 & 0 & 0 & 0 & 0 & 0 & 0 & 17 & 0 \\
\hline 0 & 0 & I & 0 & 0 & 0 & 0 & 0 & 0 & 0 & 0 & 3 & 2 \\
\hline 0 & 4 & 2 & 0 & 0 & 0 & 0 & 0 & 3 & 0 & 4 & 15 & 11 \\
\hline 2 & 0 & 0 & 0 & 0 & 0 & 0 & 1 & 0 & 0 & 0 & 106 & 4 \\
\hline 0 & 0 & 0 & 0 & 0 & 0 & 0 & 0 & 0 & 0 & 0 & 1 & 6 \\
\hline 0 & 0 & 0 & 0 & 0 & 0 & 0 & 0 & 0 & 0 & 0 & 5 & 3 \\
\hline 0 & 0 & 0 & 0 & 0 & 0 & 0 & 0 & 0 & 0 & 0 & 0 & I \\
\hline 0 & 21 & 0 & 0 & 0 & 2 & 0 & 1 & 0 & 0 & 0 & 24 & I \\
\hline 0 & 9 & 0 & 17 & 1 & 3 & 0 & 0 & 0 & 0 & 4 & 31 & 11 \\
\hline 4 & 27 & 0 & 17 & 0 & 68 & 35 & 23 & 16 & 25 & 16 & 358 & 113 \\
\hline 0 & 1 & 0 & 0 & 0 & 0 & 0 & 0 & 0 & 0 & 0 & 1 & 0 \\
\hline 0 & 0 & 0 & 0 & 0 & 0 & 0 & 0 & 0 & 0 & 0 & 7 & 0 \\
\hline 0 & 0 & 0 & 0 & 0 & 0 & 0 & 0 & 0 & 0 & 0 & 4 & 0 \\
\hline 0 & 0 & 0 & 0 & 0 & 0 & 0 & 0 & 0 & 0 & 0 & 3 & 3 \\
\hline 0 & 0 & 0 & 0 & 4 & 1 & 0 & 0 & 0 & 0 & 0 & I & 4 \\
\hline 0 & 3 & 0 & 0 & 0 & 11 & 0 & 0 & 1 & 0 & 0 & 18 & 1 \\
\hline 0 & 0 & 0 & 0 & 0 & 0 & I & 0 & 0 & 0 & 0 & I & 2 \\
\hline 0 & 0 & 0 & 0 & 0 & 0 & 0 & 0 & 0 & 0 & 0 & 4 & 4 \\
\hline 0 & 7 & 0 & 0 & 0 & 0 & 0 & 0 & 0 & 0 & 0 & 7 & 0 \\
\hline 0 & 0 & 0 & 0 & 0 & 0 & 0 & 0 & 0 & 0 & 0 & 4 & 0 \\
\hline 0 & 2 & 3 & 0 & 0 & 1 & 0 & 0 & 0 & 0 & 0 & 6 & 3 \\
\hline 0 & 0 & 0 & 0 & 0 & 0 & 0 & 0 & 0 & 0 & 0 & 3 & 0 \\
\hline 0 & 0 & 0 & 0 & I & 8 & 0 & 1 & 0 & 0 & 0 & 9 & 1 \\
\hline 0 & 12 & 0 & 3 & 31 & 5 & I & 0 & 0 & 0 & 0 & 24 & 32 \\
\hline 0 & 0 & 0 & 0 & 0 & 0 & I & 0 & 0 & 0 & 0 & I & 1 \\
\hline 0 & 0 & 0 & 0 & 0 & 1 & 0 & 0 & 1 & 0 & 0 & 3 & 3 \\
\hline 0 & 0 & 0 & 0 & 0 & 5 & 0 & 1 & 0 & 0 & 0 & 7 & 0 \\
\hline 0 & 7 & 1 & 2 & 7 & 0 & 5 & 6 & 0 & 0 & 0 & 17 & 17 \\
\hline 0 & 0 & 0 & 0 & 0 & 2 & 0 & 0 & 0 & 0 & 0 & 2 & I \\
\hline 0 & 0 & 0 & 0 & 0 & 3 & 0 & 0 & 0 & 0 & 0 & 5 & 3 \\
\hline 0 & 0 & 0 & 0 & 0 & 0 & 0 & 0 & 0 & 0 & 0 & 4 & 0 \\
\hline 0 & 27 & 1 & 0 & 18 & 8 & 0 & 0 & 0 & 0 & 0 & 41 & 25 \\
\hline 0 & 0 & 0 & 0 & 0 & 8 & 0 & 13 & 0 & 0 & 0 & 21 & 0 \\
\hline 0 & 0 & 0 & 0 & 0 & 0 & 0 & 0 & 0 & 0 & 0 & 11 & 0 \\
\hline 0 & 0 & 1 & 0 & 0 & 2 & 0 & 0 & 0 & 0 & 0 & 3 & 2 \\
\hline 0 & 22 & 0 & 0 & 0 & 4 & 0 & 0 & 0 & 0 & 0 & 26 & 0 \\
\hline 0 & 0 & 0 & 0 & 0 & 0 & 0 & 0 & 0 & 0 & 0 & 3 & 0 \\
\hline
\end{tabular}


File I (Continued)

\begin{tabular}{|c|c|c|c|c|c|c|c|c|c|c|c|c|c|}
\hline Species & 5-Aug & 6-Aug & 5-Sep & 6-Sep & 5-Oct & 6-Oct & 5-Nov & 6-Nov & 5-Dec & 6-Dec & 6-Jan & 7-Jan & 6-Feb \\
\hline Tephrosia & I & 0 & 0 & 0 & 0 & 0 & 0 & 0 & 0 & 0 & 0 & 0 & 0 \\
\hline Other Fabaceae & 3 & 12 & 0 & 6 & 71 & 56 & 11 & 6 & 10 & 16 & 4 & 0 & 15 \\
\hline Polyad & 0 & 0 & 0 & 2 & 0 & 2 & 0 & 0 & 0 & 3 & 4 & 3 & 62 \\
\hline Sesamum indicum & 0 & 0 & 3 & 0 & 0 & 0 & I & 0 & 2 & 0 & 0 & 0 & 0 \\
\hline Lauraceae & I & 0 & 0 & 0 & 0 & 0 & 0 & 0 & 0 & 0 & 0 & 0 & 0 \\
\hline Loranthaceae & 0 & 0 & 0 & 0 & I & 0 & 0 & 0 & 0 & 0 & 0 & 0 & 0 \\
\hline Lawsonia & 0 & 0 & 0 & 0 & 0 & 0 & 0 & 0 & 0 & 0 & 0 & 0 & 0 \\
\hline Hibiscus & 0 & 0 & 0 & 0 & I & 0 & 0 & 0 & 0 & 0 & 0 & 0 & 0 \\
\hline Azadirachta & 0 & 0 & 0 & 0 & 0 & 0 & 0 & 0 & 0 & 0 & 0 & 0 & 0 \\
\hline Other Meliaceae & 0 & 0 & 0 & 0 & 0 & 0 & 0 & 0 & 0 & 0 & 0 & 0 & 0 \\
\hline Monocot & 16 & 3 & 7 & 18 & 4 & 5 & 4 & 6 & I & 0 & 4 & 0 & 11 \\
\hline Morus & 2 & 0 & 5 & 1 & 6 & 10 & I & I & 4 & 0 & I & 0 & 875 \\
\hline Moringa & 0 & 0 & 0 & 0 & 0 & 0 & 0 & 0 & 0 & 0 & 0 & 0 & 4 \\
\hline Callistemon & 2 & 0 & 0 & 0 & 0 & 0 & 0 & 0 & 2 & 0 & 0 & 0 & 4 \\
\hline Eucalyptus & 0 & 0 & 0 & 2 & 0 & 0 & 2 & 0 & 2 & 0 & 6 & 12 & 12 \\
\hline Psidium & 0 & 17 & 0 & 0 & I & 0 & 0 & 0 & 0 & 0 & 0 & 0 & 2 \\
\hline Syzygium jambosa & 0 & 0 & 0 & 0 & 0 & 0 & 0 & 0 & 0 & 0 & 0 & 0 & 0 \\
\hline Bougainvillea & 0 & 0 & 0 & 0 & 0 & 0 & 0 & 0 & 0 & 0 & 0 & 0 & 0 \\
\hline Jasminum & 0 & 0 & 0 & 0 & 0 & 0 & 0 & 0 & 2 & 0 & 0 & 0 & 0 \\
\hline Palmae & 0 & 2 & 0 & 0 & 0 & 0 & 0 & 3 & 0 & 4 & 0 & 0 & 0 \\
\hline Pinus & 0 & 0 & I & 1 & 0 & 3 & 0 & 0 & 0 & 0 & 0 & 0 & 2 \\
\hline Argemone & I & 0 & 0 & 1 & 0 & 0 & 3 & 0 & 0 & 0 & 0 & 0 & 0 \\
\hline Papaver & 0 & 0 & 0 & 0 & 0 & 0 & 0 & 0 & 0 & 0 & 0 & 0 & 6 \\
\hline Plumbago & 0 & 0 & 0 & I & 0 & 0 & 0 & 0 & 0 & 0 & 0 & 0 & 0 \\
\hline Poaceae_wild & 395 & 330 & 157 & 89 & 147 & 78 & 61 & 141 & 28 & 36 & 46 & 10 & 242 \\
\hline Poaceae_cultivated & 0 & I & 0 & 17 & 20 & 21 & 5 & 5 & 5 & 0 & I & 0 & 17 \\
\hline Rumex & 0 & 0 & 0 & 0 & 0 & 0 & 0 & 0 & 0 & 0 & 0 & 9 & 0 \\
\hline Portulaca & 0 & 2 & 87 & 0 & 2 & 0 & 4 & 0 & 0 & 0 & 0 & 0 & 0 \\
\hline Zizyphus & 0 & 0 & 0 & 0 & 0 & 12 & 0 & 0 & 0 & 0 & 0 & 0 & 0 \\
\hline Ixora & I & 0 & 27 & 0 & 10 & 0 & 0 & 0 & I & 0 & 0 & 0 & 0 \\
\hline Agale & 0 & 0 & 0 & 0 & 0 & 0 & 0 & 0 & 0 & 1 & 0 & 0 & 0 \\
\hline Citrus & 0 & 0 & I & 0 & 0 & 0 & 0 & 0 & 0 & 2 & 11 & 0 & 3 \\
\hline Limonia & 0 & 0 & 0 & 0 & 2 & 0 & 0 & 0 & 0 & 0 & 0 & 0 & 0 \\
\hline Other Rutaceae & 0 & 0 & 0 & 0 & 0 & 0 & 0 & 0 & 0 & 0 & 0 & 0 & 0 \\
\hline Sapindaceae & 0 & 0 & 0 & I & 0 & 0 & 0 & 0 & 0 & 0 & 0 & 0 & 0 \\
\hline Mimusops & 0 & 0 & 0 & 1 & 0 & I & 0 & 0 & 0 & 0 & 0 & 0 & 0 \\
\hline Other Sapotaceae & 0 & 0 & 0 & 0 & 0 & 0 & 0 & 0 & 0 & 0 & 0 & 0 & 0 \\
\hline Scoparia & 0 & 0 & 0 & 0 & 0 & 0 & 0 & 0 & 0 & 0 & 0 & 0 & 0 \\
\hline Russelia & 0 & 0 & 0 & 19 & I & 0 & 0 & 0 & 0 & 0 & 0 & 0 & 0 \\
\hline Ailanthus & 0 & 0 & 0 & 0 & 0 & 0 & 0 & 0 & 0 & 0 & 0 & 0 & 256 \\
\hline Solanaceae & 0 & 0 & 0 & 1 & 0 & 0 & I & 0 & 0 & 0 & I & 0 & 0 \\
\hline Pentapetes & 0 & 0 & 0 & 0 & I & 0 & 0 & 0 & 0 & 0 & 0 & 0 & 0 \\
\hline Umbelliferae & 0 & 0 & 0 & 0 & 2 & 0 & 0 & 0 & 0 & 0 & 0 & 0 & 0 \\
\hline Holoptelea & 0 & 0 & 0 & 0 & 0 & 0 & 0 & 0 & 0 & 0 & 0 & 0 & 1149 \\
\hline Other Urticaceae & 0 & 0 & 0 & 0 & 0 & 0 & 0 & 0 & 0 & 0 & 0 & 0 & 2 \\
\hline
\end{tabular}




\begin{tabular}{|c|c|c|c|c|c|c|c|c|c|c|c|c|}
\hline 7-Feb & 6-Mar & 7-Mar & 6-Apr & 7-Apr & 6-May & 7-May & 6-Jun & 7-Jun & 6-Jul & 7-Jul & $\begin{array}{l}\text { Total } \\
\text { pollen_I st year }\end{array}$ & $\begin{array}{l}\text { Total } \\
\text { pollen_2nd year }\end{array}$ \\
\hline 0 & 0 & 0 & 0 & 0 & 0 & 0 & 0 & 0 & 0 & 0 & I & 0 \\
\hline 0 & 0 & 1 & 45 & 0 & 17 & 2 & 11 & 13 & 47 & 8 & 234 & 120 \\
\hline 8 & 72 & I & 32 & 0 & 0 & 7 & 1 & 9 & 0 & 0 & $|7|$ & 35 \\
\hline 0 & 0 & 0 & 0 & 0 & 0 & 0 & 0 & 0 & 0 & 0 & 6 & 0 \\
\hline 0 & 0 & 0 & 0 & 0 & 0 & 0 & 0 & 0 & 0 & 0 & I & 0 \\
\hline 0 & 0 & 0 & 0 & 0 & 0 & 0 & 0 & 0 & 0 & 0 & I & 0 \\
\hline 0 & 0 & 0 & 0 & 0 & 0 & 1 & 2 & I & 0 & 0 & 2 & 2 \\
\hline 0 & 0 & 0 & 0 & 0 & 1 & 0 & 1 & 0 & 0 & 0 & 3 & 0 \\
\hline 0 & 0 & 0 & 8 & 9 & 0 & I & 0 & 3 & 0 & 0 & 8 & 13 \\
\hline 0 & 2 & 0 & I & 0 & 0 & 0 & 0 & 0 & 0 & 0 & 3 & 0 \\
\hline 5 & 5 & 0 & 2 & 6 & 11 & 3 & 3 & 3 & 3 & 16 & 71 & 65 \\
\hline 6 & 2 & 317 & 3 & 7 & 4 & 0 & 3 & I & 12 & 0 & 918 & 343 \\
\hline 3 & 0 & 0 & 0 & 22 & 0 & 0 & 0 & 0 & 0 & 0 & 4 & 25 \\
\hline 10 & 0 & 2 & 2 & 0 & I & 0 & 0 & 0 & 0 & 0 & 11 & 12 \\
\hline 0 & 7 & 0 & 14 & 0 & 9 & 0 & 0 & 0 & 0 & 0 & 52 & 14 \\
\hline 0 & 0 & 0 & 0 & 0 & 0 & 4 & 0 & 0 & 0 & 0 & 3 & 21 \\
\hline 0 & 0 & 0 & 0 & 0 & 13 & 0 & 2 & 0 & 0 & 0 & 15 & 0 \\
\hline 0 & I & 2 & 0 & 0 & 0 & 0 & 0 & 0 & 0 & 0 & 1 & 2 \\
\hline 0 & 0 & 0 & 0 & 0 & 0 & 0 & 0 & 0 & 0 & 0 & 2 & 0 \\
\hline 2 & 0 & 0 & I & 0 & I & 7 & 1 & 2 & 2 & 0 & 5 & 20 \\
\hline 0 & 6 & 4 & 0 & 0 & 0 & 0 & 0 & 0 & 0 & 0 & 9 & 8 \\
\hline 0 & 0 & 0 & 0 & I & 3 & I & 0 & 0 & 0 & 0 & 7 & 3 \\
\hline 0 & 0 & 0 & 0 & 0 & 0 & 0 & 0 & 0 & 0 & 0 & 6 & 0 \\
\hline 0 & 0 & 0 & 0 & 0 & 0 & I & 0 & 0 & 0 & 0 & 0 & 2 \\
\hline 24 & 98 & 87 & 78 & 63 & 52 & 34 & 44 & 47 & 56 & 36 & 1404 & 975 \\
\hline 6 & 1 & 8 & 7 & 1 & 11 & 0 & 9 & 9 & 3 & 4 & 79 & 72 \\
\hline 0 & 4 & 0 & 0 & 0 & 0 & 0 & 0 & 0 & 0 & 0 & 4 & 9 \\
\hline 0 & 0 & 0 & 0 & 0 & 0 & 0 & 0 & 0 & 0 & 0 & 93 & 2 \\
\hline 0 & 0 & 0 & 0 & 0 & 0 & 0 & 0 & 0 & 0 & 0 & 0 & 12 \\
\hline 0 & 0 & 0 & 0 & 0 & 0 & 0 & 0 & 0 & 0 & 0 & 39 & 0 \\
\hline 0 & 0 & 1 & 0 & 1 & 0 & 0 & 0 & 0 & 0 & 0 & 0 & 3 \\
\hline 0 & 0 & 0 & 3 & 0 & 0 & 1 & 0 & 0 & 10 & 0 & 28 & 3 \\
\hline 0 & 0 & 0 & 0 & 0 & 0 & 0 & 0 & 0 & 0 & 0 & 2 & 0 \\
\hline 0 & 0 & 0 & 0 & 0 & 0 & 0 & 0 & 0 & 0 & 0 & 0 & 0 \\
\hline 0 & 0 & 0 & 0 & 0 & 0 & 0 & 0 & 0 & 0 & 0 & 0 & I \\
\hline 0 & 0 & 0 & 0 & 0 & 0 & 0 & 0 & I & 5 & 12 & 5 & 15 \\
\hline 0 & I & 0 & 0 & 0 & I & 0 & 0 & 0 & 0 & 0 & 2 & 0 \\
\hline 0 & 0 & 0 & 0 & 0 & 0 & 1 & 0 & 0 & 0 & 0 & 0 & I \\
\hline I & 0 & 0 & 0 & 0 & 0 & 0 & 0 & 0 & 0 & 0 & 1 & 20 \\
\hline 0 & 24 & 4 & 6 & 11 & 0 & 0 & 0 & 0 & 0 & 0 & 286 & 15 \\
\hline 0 & 0 & 0 & 0 & 0 & 0 & 0 & 0 & 0 & 0 & 0 & 2 & I \\
\hline 0 & 0 & 0 & 0 & 0 & 0 & 0 & 0 & 0 & 0 & 0 & 1 & 0 \\
\hline 0 & 0 & 0 & 0 & 0 & 0 & 0 & 0 & 0 & 0 & 0 & 2 & 0 \\
\hline 0 & 61 & 2072 & 0 & 4 & 6 & 0 & 1 & 0 & 0 & 0 & 1217 & 2076 \\
\hline 0 & 0 & 0 & 0 & 0 & 0 & 0 & 0 & 0 & 0 & 0 & 2 & 0 \\
\hline
\end{tabular}


File 2

\begin{tabular}{|c|c|c|c|c|}
\hline Species & Total pollen_Ist year & Total pollen_IInd year & $2005-06$ & 2006-07 \\
\hline Ruellia & 2 & 0 & I & 0 \\
\hline Polyalthia & 41 & 21 & 5.357552 & 4.392317 \\
\hline Amaranthus/Chenopodium & 121 & 61 & 6.918863 & 5.930737 \\
\hline Alternanthera & 3 & 0 & I.584963 & 0 \\
\hline Coriandrum & 4 & 0 & 2 & 0 \\
\hline Nerium & 11 & 4 & 3.459432 & 2 \\
\hline Vinca & 2 & 0 & I & 0 \\
\hline Tabernemontana & I & 0 & 0 & 0 \\
\hline Other Apocyanaceae & 12 & 1 & 3.584963 & 0 \\
\hline Ageratum & 107 & 27 & $6.74 \mid 467$ & 4.754888 \\
\hline Annual Chrysanthemum & 19 & 0 & 4.247928 & 0 \\
\hline Artemisia & 13 & 1 & 3.70044 & 0 \\
\hline Eclipta & 1 & I & 0 & 0 \\
\hline Parthenium & 3 & 0 & 1.584963 & 0 \\
\hline Xanthium & 2 & 0 & I & 0 \\
\hline Other Asteraceae & 2 & 1 & I & 0 \\
\hline Alnus & 4 & 11 & 2 & 3.459432 \\
\hline Bignonia tudiana & 17 & 0 & 4.087463 & 0 \\
\hline Tecoma & 3 & 2 & 1.584963 & I \\
\hline Bombax & 15 & 11 & 3.906891 & 3.459432 \\
\hline Chorisia & 106 & 4 & 6.72792 & 2 \\
\hline Heliotropium indicum & 1 & 6 & 0 & 2.584963 \\
\hline Brassica & 5 & 3 & 2.321928 & 1.584963 \\
\hline Iberis & 0 & 1 & 0 & 0 \\
\hline Other Brassicaceae & 24 & $\mathrm{I}$ & 4.584963 & 0 \\
\hline Canna & 31 & 11 & 4.954196 & 3.459432 \\
\hline Cannabis & 358 & 113 & 8.483816 & 6.820179 \\
\hline Capparadaceae & 1 & 0 & 0 & 0 \\
\hline Stellaria & 7 & 0 & 2.807355 & 0 \\
\hline Dianthus & 4 & 0 & 2 & 0 \\
\hline Other Caryophyllaceae & 3 & 3 & 1.584963 & 1.584963 \\
\hline Casurina & 1 & 4 & 0 & 2 \\
\hline Termanalia & 18 & 1 & 4.169925 & 0 \\
\hline Cucurbit type & 1 & 2 & 0 & I \\
\hline Cyperaceae & 4 & 4 & 2 & 2 \\
\hline Shorea & 7 & 0 & 2.807355 & 0 \\
\hline Other Dipterocarpaceae & 4 & 0 & 2 & 0 \\
\hline Ephedra & 6 & 3 & 2.584963 & 1.584963 \\
\hline Acalypha & 3 & 0 & 1.584963 & 0 \\
\hline Croton & 9 & 1 & 3.169925 & 0 \\
\hline Emblica & 24 & 32 & 4.584963 & 5 \\
\hline Jatropha & 1 & 1 & 0 & 0 \\
\hline Kirganalia & 3 & 3 & 1.584963 & 1.584963 \\
\hline Phyllanthus & 7 & 0 & 2.807355 & 0 \\
\hline Putranjiva & 17 & 17 & 4.087463 & 4.087463 \\
\hline Ricinus & 2 & 1 & I & 0 \\
\hline Other Euphorbiaceae & 5 & 3 & 2.321928 & 1.584963 \\
\hline Bahunia & 4 & 0 & 2 & 0 \\
\hline Cassia & 41 & 25 & 5.357552 & 4.643856 \\
\hline Cassia siamea & 21 & 0 & 4.392317 & 0 \\
\hline Calliandra & 11 & 0 & 3.459432 & 0 \\
\hline Pongamia type & 3 & 2 & I.584963 & I \\
\hline Prosopis & 26 & 0 & 4.70044 & 0 \\
\hline Sesbania type & 3 & 0 & I.584963 & 0 \\
\hline Tephrosia & 1 & 0 & 0 & 0 \\
\hline Other Fabaceae & 234 & 120 & 7.870365 & 6.906891 \\
\hline
\end{tabular}


File 2 (Continued)

\begin{tabular}{|c|c|c|c|c|}
\hline Species & Total pollen_Ist year & Total pollen_IInd year & 2005-06 & 2006-07 \\
\hline Polyad & I7I & 35 & 7.417853 & 5.129283 \\
\hline Sesamum indicum & 6 & 0 & 2.584963 & 0 \\
\hline Lauraceae & 1 & 0 & 0 & 0 \\
\hline Loranthaceae & $\mathrm{I}$ & 0 & 0 & 0 \\
\hline Lawsonia & 2 & 2 & I & 1 \\
\hline Hibiscus & 3 & 0 & 1.584963 & 0 \\
\hline Azadirachta & 8 & 13 & 3 & 3.70044 \\
\hline Other Meliaceae & 3 & 0 & 1.584963 & 0 \\
\hline Monocot & 71 & 65 & 6.149747 & 6.022368 \\
\hline Morus & 918 & 343 & 9.84235 & 8.422065 \\
\hline Moringa & 4 & 25 & 2 & 4.643856 \\
\hline Callistemon & 11 & 12 & 3.459432 & 3.584963 \\
\hline Eucalyptus & 52 & 14 & 5.70044 & 3.807355 \\
\hline Psidium & 3 & 21 & 1.584963 & 4.392317 \\
\hline Syzygium jambosa & 15 & 0 & 3.906891 & 0 \\
\hline Bougainvillea & I & 2 & 0 & I \\
\hline Jasminum & 2 & 0 & I & 0 \\
\hline Palmae & 5 & 20 & 2.321928 & 4.321928 \\
\hline Pinus & 9 & 8 & 3.169925 & 3 \\
\hline Argemone & 7 & 3 & 2.807355 & 1.584963 \\
\hline Papaver & 6 & 0 & 2.584963 & 0 \\
\hline Plumbago & 0 & 2 & 0 & I \\
\hline Poaceae_wild & 1404 & 975 & 10.45533 & 9.929258 \\
\hline Poaceae_cultivated & 79 & 72 & 6.303781 & 6.169925 \\
\hline Rumex & 4 & 9 & 2 & 3.169925 \\
\hline Portulaca & 93 & 2 & 6.539159 & I \\
\hline Zizyphus & 0 & 12 & 0 & 3.584963 \\
\hline Ixora & 39 & 0 & 5.285402 & 0 \\
\hline Agale & 0 & 3 & 0 & I.584963 \\
\hline Citrus & 28 & 3 & 4.807355 & 1.584963 \\
\hline Limonia & 2 & 0 & I & 0 \\
\hline Other Rutaceae & 0 & 0 & 0 & 0 \\
\hline Sapindaceae & 0 & 1 & 0 & 0 \\
\hline Mimusops & 5 & 15 & 2.321928 & 3.906891 \\
\hline Other Sapotaceae & 2 & 0 & I & 0 \\
\hline Scoparia & 0 & I & 0 & 0 \\
\hline Russelia & I & 20 & 0 & 4.321928 \\
\hline Ailanthus & 286 & 15 & $8 .|5987|$ & 3.906891 \\
\hline Solanaceae & 2 & $\mathrm{I}$ & I & 0 \\
\hline Pentapetes & 1 & 0 & 0 & 0 \\
\hline Umbelliferae & 2 & 0 & I & 0 \\
\hline Holoptelea & 1217 & 2076 & $|0.249| \mid$ & 11.01959 \\
\hline Other Urticaceae & 2 & 0 & I & 0 \\
\hline
\end{tabular}


File 3 (Sheet I) Principal components analysis

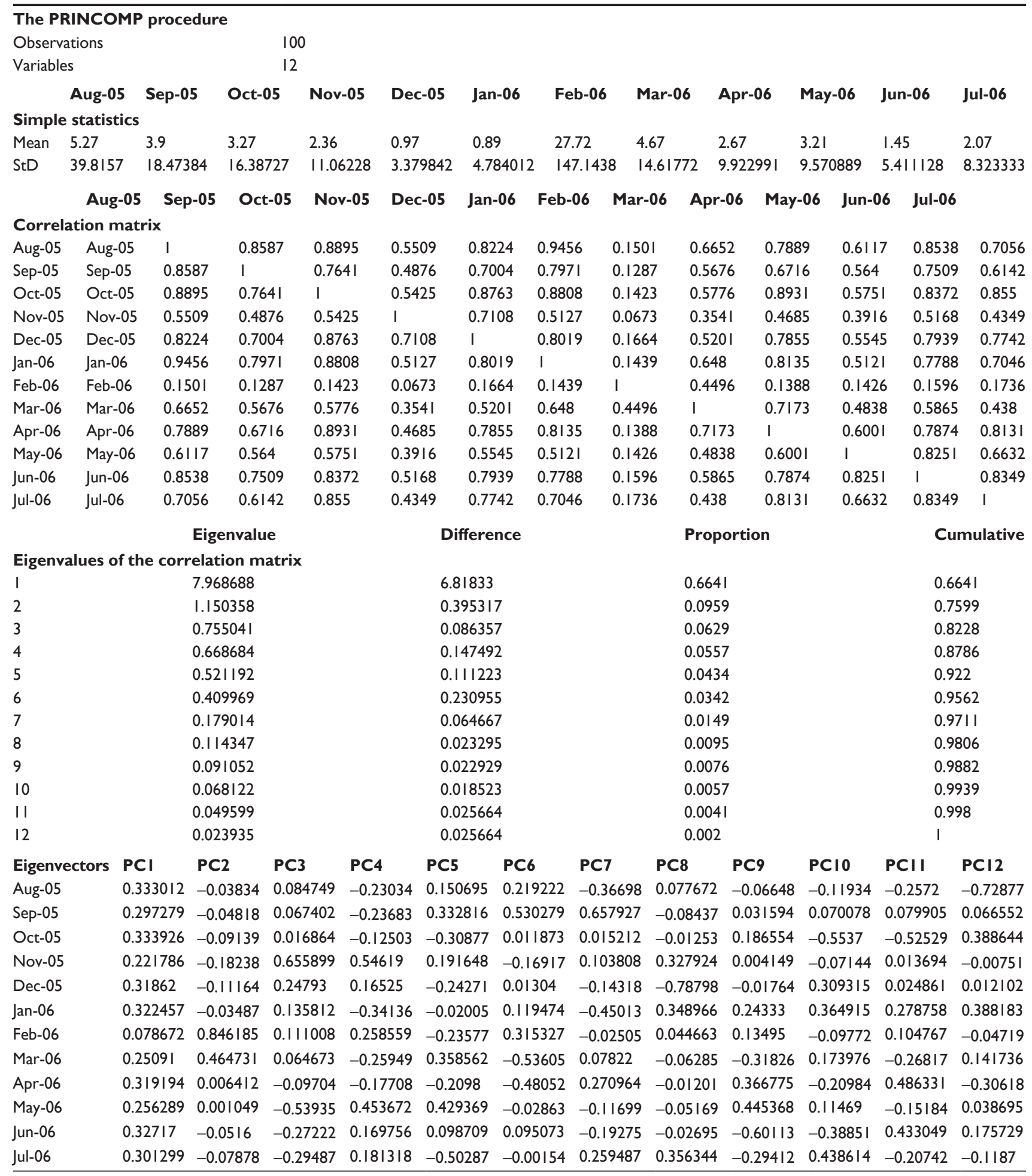

Generated by the SAS System (Local, XP_PRO) on IODEC2008 at 2:45 PM 
File 3 (Sheet 2)

\begin{tabular}{|c|c|c|c|c|c|c|c|c|c|c|c|c|c|c|c|c|c|c|c|c|c|c|}
\hline \multicolumn{23}{|c|}{ The PRINCOMP procedure } \\
\hline \multicolumn{7}{|c|}{ Observations } & \multicolumn{16}{|c|}{ Apr-00 } \\
\hline \multicolumn{7}{|c|}{ Variables } & \multicolumn{16}{|c|}{ Jan-00 } \\
\hline & \multicolumn{2}{|c|}{ Aug-06 } & \multicolumn{2}{|c|}{ Sep-06 } & \multicolumn{2}{|c|}{ Oct-06 } & \multicolumn{2}{|c|}{ Nov-06 } & \multicolumn{2}{|c|}{ Dec-06 } & \multicolumn{2}{|c|}{ Jan-07 } & \multicolumn{3}{|c|}{ Feb-07 } & \multicolumn{2}{|c|}{ Mar-07 } & \multicolumn{2}{|c|}{ Apr-07 } & May-07 & Jun-07 & Jul-07 \\
\hline Simple & statisti & & & & & & & & & & & & & & & & & & & & & \\
\hline Mean & Jan-00 & & 1.83 & & 2.09 & & 1.71 & & 0.92 & & 0.65 & & 0.7 & & & 25.25 & & 1.93 & & 1.3 & 1.21 & 1.04 \\
\hline StD & Feb-00 & & 9.3884 & & 9.872 & 004 & 14.11 & & 4.121 & 1096 & 2.24 & 10017 & & 0982 & & 209.3 & 3247 & 7.622 & 274 & 5.236816 & 5.278688 & 4.462911 \\
\hline & Aug- & & Sep & -06 & Oct & -06 & Nov- & & Dec- & & Jan-0 & & Feb-0 & & Mar-C & -07 & Apr-0 & & May-07 & Jun- 07 & Jul-07 & \\
\hline Correla & ation $\mathrm{m}$ & latri & & & & & & & & & & & & & & & & & & & & \\
\hline Aug-06 & Aug-C & & 1 & & 0.94 & & 0.794 & & 0.994 & & 0.883 & & 0.4253 & & 0.8115 & & $0.027 \mid$ & & 0.8036 & 0.673 & 0.9009 & 0.8187 \\
\hline Sep-06 & Sep-0 & & 0.94 & & 1 & & 0.811 & & 0.950 & & 0.840 & & 0.428 & & 0.8445 & & 0.0189 & & 0.7623 & 0.6379 & $0.896 I$ & 0.8519 \\
\hline Oct-06 & Oct- & & 0.79 & & 0.81 & & I & & 0.806 & & 0.889 & & 0.3614 & & $0.705 \varepsilon$ & & 0.0249 & & 0.6248 & 0.5202 & 0.8655 & 0.7489 \\
\hline Nov-06 & Nov- & & 0.99 & & 0.95 & & 0.806 & & I & & 0.875 & & 0.415 & & 0.8182 & & 0.0285 & & 0.8096 & 0.6339 & 0.8915 & 0.8132 \\
\hline Dec-06 & Dec- & & 0.88 & & 0.84 & & 0.889 & & 0.875 & & 1 & & 0.4007 & & 0.738 & & 0.0102 & & 0.7091 & 0.7252 & 0.9313 & 0.8218 \\
\hline Jan-07 & Jan- 0 & & 0.42 & & 0.42 & & 0.361 & & 0.415 & & 0.400 & & I & & $0.444 \mid$ & & -0.012 & & 0.315 & 0.3595 & 0.4291 & $0.360 \mathrm{I}$ \\
\hline Feb-07 & Feb- 0 & & 0.81 & & 0.84 & & 0.705 & & 0.818 & & 0.738 & & $0.444 I$ & & 1 & & 0.0369 & & 0.6919 & 0.6345 & 0.8326 & 0.7412 \\
\hline Mar-07 & Mar-C & & 0.027 & & 0.01 & & 0.024 & & 0.028 & & 0.010 & & -0.012 & & 0.0369 & & I & & IוI & -0.002 & 0.0138 & 0.006 \\
\hline Apr-07 & Apr-C & & 0.80 & & 0.76 & & $0.624 \varepsilon$ & & 0.809 & & 0.709 & & 0.315 & & 0.6919 & & I I & & 1 & 0.5182 & 0.7035 & 0.6459 \\
\hline May-07 & May- & & 0.67 & & 0.63 & & 0.520 & & 0.633 & & 0.725 & & 0.3595 & & 0.6345 & & -0.002 & & 0.5182 & I & 0.7855 & 0.7454 \\
\hline Jun-07 & Jun-0 & & 0.90 & & 0.89 & & 0.865 & & 0.891 & & 0.9313 & & 0.4291 & & 0.8326 & & 0.0138 & & 0.7035 & 0.7855 & I & 0.8859 \\
\hline Jul-07 & Jul-07 & & $0.81 \varepsilon$ & & 0.85 & & 0.748 & & 0.813 & & $0.821 \varepsilon$ & & 0.3601 & & 0.7412 & & 0.006 & & 0.6459 & 0.7454 & 0.8859 & 1 \\
\hline & & & & Eige & envalu & & & & & Dif & feren & & & & & & Propo & ortic & & & Cun & mulative \\
\hline Eigenva & alues of & f t & corr & relati & ion $\mathbf{m}$ & atr & & & & & & & & & & & & & & & & \\
\hline 1 & & & & 8.325 & 5067 & & & & & 7.3 & 14289 & & & & & & 0.6938 & & & & 0.69 & 938 \\
\hline 2 & & & & 1.01 & 0778 & & & & & 0.2 & II 047 & & & & & & 0.0842 & & & & 0.77 & \\
\hline 3 & & & & 0.79 & 9731 & & & & & 0.2 & 05615 & & & & & & 0.0666 & & & & 0.84 & 446 \\
\hline 4 & & & & 0.59 & 4116 & & & & & 0.15 & 54582 & & & & & & 0.0495 & & & & 0.89 & 941 \\
\hline 5 & & & & 0.43 & 9534 & & & & & 0.1 & 49007 & & & & & & 0.0366 & & & & 0.93 & 308 \\
\hline 6 & & & & 0.29 & 0527 & & & & & 0.0 & 75862 & & & & & & 0.0242 & & & & 0.95 & \\
\hline 7 & & & & 0.21 & 4665 & & & & & 0.0 & 39384 & & & & & & 0.0179 & & & & 0.97 & 729 \\
\hline 8 & & & & 0.17 & 5281 & & & & & 0.1 & 07442 & & & & & & 0.0146 & & & & 0.98 & 875 \\
\hline 9 & & & & 0.06 & 7839 & & & & & 0.0 & $2756 \mid$ & & & & & & 0.0057 & & & & 0.99 & 931 \\
\hline 10 & & & & 0.04 & 0277 & & & & & 0.0 & 00977 & & & & & & 0.0034 & & & & 0.99 & 965 \\
\hline 11 & & & & 0.03 & & & & & & 0.0 & $364 \mid 4$ & & & & & & 0.0033 & & & & 0.99 & 998 \\
\hline 12 & & & & 0.00 & 2886 & & & & & 0.0 & $364 \mid 4$ & & & & & & 0.0002 & & & & 1 & \\
\hline Eigenve & ectors & PC & & PC & & $P C$ & 23 & PC4 & & PC5 & & PC6 & & $\mathbf{P C}$ & & PC & & PC & & PCIO & PCII & PCI 2 \\
\hline Aug-06 & & 0.33 & 33029 & 0.0 & 17245 & & .06069 & -0.16 & 6021 & 0.098 & 3025 & $0.04 \mid$ & $|38|$ & -0.2 & |2697| & & .41752 & & 14756 & $0.2555 \mid 3$ & -0.21642 & -0.68349 \\
\hline Sep-06 & & 0.32 & 29952 & 0.0 & 05939 & & .04794 & -0.16 & 6249 & 0.017 & 728 & -0.2 & 4128 & -0.3 & 32387 & & .07287 & & 3928 & -0.42526 & 0.467348 & -0.05987 \\
\hline Oct-06 & & 0.29 & 99843 & 0.0 & 09006 & & 10564 & -0.13 & 374 & -0.64 & 4957 & 0.115 & 5351 & & 05384 & & | $5073 \mid$ & & 16535 & 0.383127 & -0.08696 & -0.03001 \\
\hline Nov-06 & & 0.33 & 31906 & 0.02 & 23937 & & .07553 & -0.22 & 2538 & 0.072 & 335 & -0.00 & 0556 & & 27238 & & .36903 & -0 & 09513 & 0.253053 & -0.13985 & 0.724215 \\
\hline Dec-06 & & 0.32 & 24205 & -0. & 01813 & & .08285 & 0.090 & 0752 & -0.28 & 3486 & 0.342 & 2285 & & 91527 & & .14343 & & 54577 & -0.21162 & 0.530295 & 0.006304 \\
\hline Jan-07 & & 0.16 & 8038 & -0 . & 12539 & & 59068 & -0.10 & 0532 & -0.04 & 4711 & 0.123 & 3104 & & 05766 & & 655283 & & .0048 & 0.005376 & -0.00832 & 0.007498 \\
\hline Feb-07 & & 0.30 & 2367 & 0.0 & 16154 & & 71157 & -0.07 & 7168 & 0.189 & & -0.73 & 3709 & 0.49 & 99886 & & 47647 & & 20733 & 0.126161 & 0.08617 & -0.02096 \\
\hline Mar-07 & & 0.00 & 9587 & 0.98 & 82615 & & 36134 & 0.108 & 8435 & -0.05 & 5318 & -0.00 & 0638 & & .03011 & & .01438 & & .00387 & -0.00709 & 0.006152 & 0.000844 \\
\hline Apr-07 & & 0.27 & 78544 & 0.10 & $0505 \mathrm{I}$ & & 12048 & -0.40 & 0285 & 0.554 & 376 & 0.45 I & 1289 & & .55553 & & 385756 & & 7925 & -0.04416 & -0.034 & -0.00902 \\
\hline May-07 & & 0.26 & 3087 & -0 & 06875 & & 45558 & 0.755 & $574 \mid$ & 0.329 & 337 & 0.176 & 6209 & 0.16 & 68614 & & .19387 & & 16773 & 0.201149 & $0.07025 I$ & 0.039621 \\
\hline Jun-07 & & 0.33 & 35072 & -0 & 02276 & & .04229 & 0.175 & 5051 & -0.15 & 5087 & -0.02 & 2646 & & 03743 & & .00707 & & .04149 & -0.6359 & -0.64249 & 0.040219 \\
\hline Jul-07 & & 0.31 & 10191 & -0 & 02983 & & .09221 & 0.279 & 9214 & -0.04 & 4756 & -0.12 & 252 & & .50952 & & 669119 & & 23583 & 0.18838 & $-3.1 \mathrm{E}-05$ & -0.0076 \\
\hline
\end{tabular}

Generated by the SAS System (Local, XP_PRO) on IODEC2008 at 2:45 PM 
Research and Reports in Biodiversity Studies

Dovepress

\section{Publish your work in this journal}

Research and Reports in Biodiversity Studies is an international, peerreviewed, open access journal publishing original research, reports, reviews and commentaries on all areas of biodiversity research. The manuscript management system is completely online and includes a

very quick and fair peer-review system. Visit http://www.dovepress.com/ testimonials.php to read real quotes from published authors. 